\title{
CEOs' Outside Employment Opportunities and the Lack of Relative Performance Evaluation in Compensation Contracts
}

\author{
SHIVARAM RAJGOPAL, TERRY SHEVLIN and VALENTINA ZAMORA*
}

\begin{abstract}
Although agency theory suggests that firms ought to index executive compensation to remove market-wide effects (i.e., RPE), there is little evidence to support this theory. Oyer (2004) posits that absence of RPE is optimal if the CEO's reservation wages from outside employment opportunities rise and fall with the economy's fortunes. We directly test and find support for Oyer's (2004) theory. We argue that the CEO's outside opportunities depend on his talent proxied by the CEO's financial press visibility and his firm's recent industry-adjusted ROA. Our results are robust to alternate explanations such as managerial skimming, oligopoly and asymmetric benchmarking.
\end{abstract}

\footnotetext{
* Rajgopal and Shevlin are from the University of Washington; and Zamora is from Boston College. Rajgopal and Shevlin acknowledge support from the Accounting Development Fund at the University of Washington. Zamora acknowledges support from Boston College. We acknowledge written comments from an anonymous referee, Luzi Hail, Frank Hodge and Dawn Matsumoto and verbal comments from James Jiambalvo, Eric Noreen, Jane Kennedy and other workshop participants at the University of Washington. We thank Jennifer Francis, Allen Huang and Li Zang for graciously agreeing to share their CEO press citations data with us.
} 
Agency theory predicts that the market component of a firm's returns should be removed from the compensation package since executives cannot affect the overall market by their actions and it is costly for the executive to bear the relative risks. Such market indexing of compensation is also referred to as relative performance evaluation (RPE). However, there is little empirical evidence of RPE in the literature (e.g., Antle and Smith 1986, Janakiraman, Lambert and Larcker 1992). In fact, a widespread feature of CEO pay, especially those of stock option plans in recent bull markets, is that they reward managers for stock price increases due to general market trends. Proponents of the optimal contracting view argue that rewarding CEOs for riding the bull market is optimal if the CEO's reservation wage stemming from outside employment opportunities rises and falls with the economy's fortunes (Oyer 2004 and Himmelberg and Hubbard 2000). Assuming that CEO talent is scarce, the demand for talented CEOs rises as the economy booms and firms must pay CEOs more to retain them. Allowing pay to increase with rising market levels during boom periods thus potentially enables firms to retain talented executives. A direct empirical test of the outside opportunities based explanation for lack of RPE is generally missing from the literature because CEO talent is typically difficult to observe. ${ }^{1}$ We attempt to address this void in the current paper.

We focus on a sample of S\&P 500 firms for the period 1993 to 2001 and collect data on two proxies for CEO talent in these firms: (i) the number of articles containing the CEO's name that appear in the major U.S. and global business newspapers and business wire services as identified through searches of the Lexis/Nexis database; and (ii) past industry-adjusted return on assets (ROA) performance of the firm. We argue that more talented CEOs are likely to be cited and recognized by the business press more often than less talented CEOs. Moreover, talented CEOs are likely to report superior industry-adjusted ROA performance than less talented CEOs. 
To ensure that number of articles is not merely a reflection of CEO infamy as opposed to talent, we conduct three validation checks. First, we code the tone of coverage for 50 articles picked at random every year over 1993 to 2001 and find that the tone is favorable towards the CEO 95\% of the time. Second, we find that the number of articles is correlated with CEOs appointed from outside the firm, a proxy for reputation used by Milbourn (2003). Third, the number of articles is highly correlated with explicit recognition of the CEO by the "Top CEO" lists compiled by various sources. Under the outside opportunities explanation, the propensity of firms to let CEO pay "ride the bull market" should increase with these proxies for CEO talent. That is, more talented CEOs should face less RPE.

However, finding results consistent with such a prediction does not necessarily single out the optimal contracting model as a satisfactory explanation for the absence of RPE. An important alternate hypothesis, put forth by several governance activists and economists, is that rent-seeking managers exploit captured governance mechanisms to set their own pay with little shareholder oversight (e.g., Crystal 1991, Bertrand and Mullainathan 2001; Bebchuk, Fried and Walker 2002; and Bebchuk and Fried 2003). These critics argue that paying managers for market-wide increases in stock prices is inconsistent with the optimal contracting framework because such an arrangement only makes the compensation contract riskier (Holmstorm 1979). To empirically distinguish the outside opportunities view from the rent-seeking view, we investigate whether absence of RPE is increasing in proxies for poor governance and whether such an effect dominates the outside opportunities explanation for the lack of RPE.

The results, based on 2,343 CEO-firm-year observations drawn from 1993 to 2001, suggest that compensation committees do not practice RPE i.e., they do not completely filter out market-wide or industry-wide performance from the CEO's total compensation consisting of 
stock and non-stock based components. ${ }^{2}$ Consistent with the outside opportunities explanation, we find that the sensitivity of CEO compensation to market-wide and industry-wide performance is systematically higher for CEOs who enjoy (i) greater press visibility; and (ii) superior industry-adjusted ROA during the prior three years. These results are consistent with the view that market-wide shocks increase demand for CEO talent outside the firm, which in turn, forces some firms to increase compensation levels to retain their more talented CEOs.

Further analyses test the robustness of this result to several alternate explanations. First, we find a portion of the sensitivity of CEO compensation to market-wide shocks attributable to CEO talent persists after controlling for the governance quality of the firm and as such is robust to the skimming hypothesis mentioned earlier. Second, we show that the CEO talent explanation is incremental to Aggarwal and Samwick's (1999b) argument that lower RPE might be optimal in oligopolistic industries so as to prevent rival managers from indulging in excess competition. Third, when we allow for Garvey and Milbourn's (2003) hedging explanation that RPE is lower for older CEOs and CEOs with greater firm-specific wealth (as a proxy for the CEO's unobservable total wealth) because such CEOs can hedge the exposure of their compensation to market-wide shocks, our CEO talent explanation for lack of RPE still generally holds.

In the last set of analyses, we evaluate whether CEO pay is allowed to float with the market index only when the market is up but not when the market is down and whether such asymmetric benchmarking of CEO pay with the market index, interpreted as rent extraction by Bertrand and Mullainathan (2001) and Garvey and Milbourn (2004), is systematically higher or lower for talented managers. We find that CEO pay is shielded from a market downturn in most specifications although the results related to talented CEOs are mixed depending on the proxy for talent and the specific index chosen (market index or industry index). Thus, our results reveal no 
systematic pattern of asymmetric benchmarking for either talented or untalented executives to suggest that rent extraction is the dominant explanation for asymmetric benchmarking.

We contribute to the literature on executive compensation in several ways. Recent reviews of the compensation literature (Murphy 1999, Abowd and Kaplan 1999 and Prendergast 1999) identify the lack of RPE as an important unresolved puzzle. We provide evidence on an economically plausible explanation for the lack of RPE - compensation for the CEO's outside opportunities (Oyer 2004). In an unpublished working paper, Himmelberg and Hubbard (2000) exploit Rosen's (1982) insight that talented managers will be employed by larger, more complex firms, and empirically document that the sensitivity of CEO pay to systematic market-wide factors is greater for larger firms. Himmelberg and Hubbard (2000), in effect, proxy for CEO talent with firm size - a firm characteristic - whereas our proxies for CEO talent are more direct and are tied to the executive (such as media cites of the CEO name and superior industryadjusted performance under the CEO's tenure). Thus, our paper is among the first to show that a firm's use of RPE varies with the executive's characteristics. Garvey and Milbourn (2003) also relate an executive's characteristics to the lack of RPE but they focus on the role of age and CEO wealth. Unlike Garvey and Milbourn (2003), we directly control for the rent extraction explanation and test whether the CEO talent explanation still holds.

Note further that Milbourn (2003) also relies on the number of CEO media cites as a proxy for the CEO's talent and shows that such a proxy is related to the observed pay-forperformance sensitivity (PPS). Our research question of whether CEO talent explains absence of RPE is different from Milbourn's question of whether PPS is linked to CEO talent. Nevertheless, we show that the empirical relation between CEO media cites and the absence of RPE is incremental to the link between media cites and PPS found by Milbourn (2003). Finally, 
we point out that asymmetric benchmarking by itself need not indicate rent extraction by managers (Bertrand and Mullainathan 2001 and Garvey and Milbourn 2004). Shielding CEO pay from market or industry downturns has been shown to be optimal in other contexts such as option repricing (e.g., Saly 1994; Acharya, John and Sundaram 2000; Carter and Lynch 2001 and 2004; and Chidambaram and Prabhala 2003).

The remainder of the paper is as follows. Section I discusses the background literature and lays out the CEO's outside opportunities hypothesis. Section II describes the sample, the empirical specifications and the results of testing the CEO's outside opportunities hypothesis. Section III reports the robustness of the CEO's outside opportunities hypothesis to alternative hypotheses. Section IV concludes.

\section{Background and Hypothesis}

\section{A. Prior research}

Several authors present strong economic arguments for assessing an agent's performance relative to a peer group if all agents' performances are affected by a common factor such as industry-wide or market-wide returns (Baiman and Demski 1980, Diamond and Verrechhia 1982; Holmstrom, 1979, 1982). Holmstrom (1982) shows that as the number of peer agents becomes large enough to form a precise estimate of the common factor and if the actions of each agent have no effect on the performance of any other agent, then the common uncertainty should be completely filtered out of the agent's performance. Reducing the systematic risk attached to a common factor allows a better assessment of the agent's actions and thus provides a stronger incentive. The prediction, also known as the strong form version of the relative performance

evaluation (RPE) hypothesis, is that the common factor will be completely filtered out and performance evaluation will be a function of only the unsystematic component of the 
performance measure. A weaker form of the RPE hypothesis argues that if the common factor is measured with error or if the agent could influence performance of other agents, performance evaluation may be a function of both the systematic and unsystematic component of the performance measure.

For a more concrete understanding of the issue, consider a typical empirical specification where compensation is regressed on firm returns and a common factor proxied as returns to the industry.

$$
\text { Compensation }=\beta_{0}+\beta_{1} \text { Firm returns }+\beta_{2} \text { Industry returns }+\beta_{3} \text { Controls }+ \text { error }
$$

In equation (1), $\beta_{1}$ is traditionally labeled as the pay-for-performance sensitivity (PPS). Although equation (1) is written out as though the common factor is industry, we can also think of the specification in terms of market returns as the common factor. Under the strong form of RPE, $\beta_{2}$ is predicted to be negative and equal in magnitude to $\beta_{1}\left(\right.$ or $\beta_{1}+\beta_{2}=0$ ). Under the weak form of RPE, $\beta_{2}$ is predicted to be negative but less than $\beta_{1}$ in absolute magnitude. These predictions are consistent with the idea that under the strong (weak) form of RPE, the compensation committee filters out market-wide performance completely (partially) while paying managers.

The extant empirical evidence on both the weak and the strong form of RPE is mixed at best. Gibbons and Murphy (1990) find modest support for the weak form of RPE when they regress the change in the natural log of the CEO's compensation on the firm's stock returns and measures of market and industry return as proxies for peer performance. However, market and one-digit industry returns contribute a substantial portion of the explanatory power in the regression suggesting that systematic risk is imposed on executives or, in other words, executives 
are rewarded for industry and market increases. Several studies are consistent with a lack of evidence for the strong form of the RPE hypothesis and relatively mild support for the weak form of RPE (Murphy 1985, Antle and Smith 1986, Barro and Barro 1990, Sloan 1993, Janakiraman, Lambert and Larcker 1992).

Evidence supporting RPE is somewhat stronger with respect to predicting CEO turnover. Several papers report an association between CEO turnover and net-of-market stock return (e.g., Gibbons and Murphy 1990; Murphy and Zimmerman 1993; Pourciau 1993, Weisbach 1988). Recently, Defond and Park (1999) show that RPE is more closely associated with CEO turnover in high-competition industries.

Corporate governance activists such as Crystal (1991), Rappaport (1999) and Bebchuk, Fried and Walker (2002) have interpreted the limited evidence in favor of the RPE hypothesis as support for the rent extraction perspective under which managers exploit captured boards of directors to reward themselves for industry or economy wide increases in stock prices. Bertrand and Mullainathan (2001) document that pay is as sensitive to exogenous luck as it is to firmspecific performance and that the linkage with exogenous luck is stronger when shareholders are diffused and arguably passive.

An alternative explanation for the limited evidence supporting RPE is the optimal contracting perspective. For example, Janikiraman, Lambert and Larcker (1992) suggest that the lack of applicability of RPE to compensation arises because managers at higher levels might have incentives to forecast and respond to luck. They also suggest that in oligopolistic settings there are strategic interactions among firms that prevent a simple incorporation of industry index into performance evaluation. Aggarwal and Samwick (1999) argue that shareholders would be worse off if firms screened out industry-wide effects because such screening out would provide 
managers an incentive to lower industry-wide returns by engaging in excessive competition, which in turn would lower profits.

\section{B. RPE and CEO's outside opportunities}

Recently, Oyer (2004) and Himmelberg and Hubbard (2000) posit that we do not observe RPE in wage contracts because the value of the executives' outside opportunities is marketsensitive. When we observe industry or market-wide increases in stock prices, the reservation wage of talented CEOs goes up and firms pay their CEOs more simply to match their increased outside opportunities. This is because aggregate market or industry returns reflect, among other things, shocks to demand and productivity, and hence demand for managerial talent. If the supply of managerial talent is scarce and hence inelastic, then increases in aggregate market or industry returns ought to increase the equilibrium wage paid to CEOs. Moreover, if increases in aggregate market or industry returns raise the demand for CEO effort, and if such shocks can be contracted upon, then the principal will demand more effort (or talent) and compensation levels have to rise to meet the agent's reservation utility. The models proposed by Oyer (2004) and Himmelberg and Hubbard (2000) from which the above arguments are drawn, critically depend on the assumption that executive turnover is costly and adjusting the parameters of the pay scheme after observing the state of the economy is onerous. In particular, the firm may initially pay a fixed wage and upon being faced with an outside offer, the firm can adjust its wage to the market wage. In that scenario, there is no need to make part of pay contingent on market-wide returns. However, revising a flat wage to respond to an outside offer, as opposed to linking the wage to market returns, may lead to negotiation, information gathering and turnover costs to the firm. 
We provide a direct test of the CEO outside opportunities based explanation in the current paper. In particular, we argue that talented CEOs ought to have greater outside opportunities and we construct proxies for CEO talent using the frequency of media cites and recent prior industry-adjusted ROA performance of the firm. Our empirical prediction is as follows:

Hypothesis 1: The sensitivity of CEO pay to systematic market-wide factors is an increasing function of CEO's talent.

We also account for the rent-extraction explanation, the strategic influence among oligopolistic industries, hedging explanation and asymmetric benchmarking in our empirical tests as alternate explanations. These alternative explanations are developed below.

\section{Sample and Data}

\section{A. CEO talent proxies}

Our sample consists of officers named as CEOs of all S\&P 500 companies over the nineyear period 1993 to 2001 in the Execucomp database matched with firm-level data from Compustat and monthly stock return from CRSP. We focus on S\&P 500 firms for two reasons. First, talented mangers are likely to gravitate to this group of larger firms wherein we expect to find the greatest support for the outside opportunities hypothesis. Second, our CEO talent proxies are gathered through extensive hand collection of data. Hence, cost and time considerations require us to concentrate on only a subset of firms in the population. We exclude CEOs of subsidiaries and divisions.

Table I describes the data filters used to determine the sample. Our initial sample of CEO-years with data on press mentions of CEO (Articles below) consists of 464 firms and 3,487 CEO-firm years after eliminating firms with missing data on either Compustat or CRSP. 
Computing industry-adjusted average ROA over the last three years, one of our two talent proxies, entails a loss of 1,144 CEO firm-years. Of these 1,144 CEO firm-years, we lose the most observations (855 CEO firm-years) on account of our requirement that we compute ROAs over the same CEO's tenure. ${ }^{3}$ Thus, we are left with a smaller sample of 403 firms and 2,343 CEO firm-years for which both Articles and IndadjROA are available. To simplify the exposition, we only tabulate results run on these 2,343 CEO firm-years because both proxies for talent (Articles and IndajROA) are available for this sample. However, we have verified in untabulated results, that all the inferences reported in the paper hold when we consider the larger sample of 3,487 CEO firm-years for which only the Articles proxy for CEO talent is available.

\section{[INSERT TABLE I HERE]}

Our observations are evenly divided among our sample period 1993 to 2001 and in particular, 1993 contributes $9.26 \%$ of the sample whereas 2000 contributes $12.73 \%$ of the sample. Further, our sample covers a wide range of industries with the three largest industry groups in the sample coming from Electric, Gas and Sanitary Services (SIC code 4900, 8.40\% of the sample), Chemicals and Allied Products (SIC code 2800, $7.89 \%$ of the sample) and Depository Institutions (SIC code $6000,7.51 \%$ of the sample).

For each CEO-year, we collect data on several variables related to the CEO's talent. One proxy is intended to capture whether external parties view the CEO as talented. The first of these external measures is the number of articles containing the CEO's name and company affiliation that appear in the major U.S. and global business newspapers and newswires in a calendar year. ${ }^{4}$ The newspapers considered are the Wall Street Journal, New York Times, Washington Post, USA Today, Financial Times, Asian Wall Street Journal, Wall Street Journal Europe, and International Herald Tribune. Our text search uses both the CEO's last name and company 
name (e.g., Akers and International Business Machines or IBM). We include an article only once, irrespective of how many times the CEO's name appears in the article. Based on Milbourn (2003) and Francis et al. (2004), we classify CEOs with larger values of press coverage (labeled Articles) as more talented than CEOs with smaller values of these variables. ${ }^{5}$ Descriptive data on Articles appears in panel A of Table II. The median CEO gets 11 mentions in the press in a year. This count is consistent with Milbourn (2003) who finds a median of 55 mentions of the CEO's name in the Dow Jones News Service (DJNS) over a five-year period (see his Table 2A). We highlight three validation checks to ensure that the press visibility measures captures constructs such as CEO talent:

[INSERT TABLE II HERE]

(i) Tone of coverage: We randomly pick 50 articles every year over the nine-year period 1993 to 2001 and classify the tone of the articles in which the CEO is mentioned as favorable, unfavorable and neutral. More than $95 \%$ of the articles are neutral or favorable.

(ii) Prior position: Milbourn (2003) argues that CEOs appointed from outside the firm are more-reputed CEOs because the hurdle for hiring an outside CEO is higher than hiring an inside CEO, since we expect insiders have the advantage of possessing firmspecific knowledge. We find that the (untabulated) correlation between a dummy, PRIOR, which is set equal to one if the CEO is hired from outside, and Articles, is 0.06 ( $p$-value $<0.01)$. Thus, Articles captures the outside hire aspect of CEO talent.

(iii) Explicit recognition: Francis et al. (2004) show that the press visibility measure is positively correlated with explicit recognition of the CEO as a top manager by business publications. In particular, the authors code a Top dummy as one (zero) for 
a fiscal year if the CEO is recognized (not recognized) as a top manager in any one of the following lists: Business Week's list of "The Best Managers" (available 1992 to 2001), Worth's list of the "The Best CEO's" (available 1999 to 2001), the Financial Times' list of the "World's Most Respected Business Leaders" (available 1998 to 2001), Time's list of “The Time/CNN 25 Most Influential" (available for 2001), and Fortune's lists of the "The 50 Most Powerful Women in Business" (available 1998 to 2001) and the "Most Powerful Black Executives in America" (available 1998 to 2001). ${ }^{6}$ Descriptive data in panel A of Table II shows that $2 \%$ of the CEOs in the sample have been rated as "Top CEOs" by newspapers and magazines. As reported in panel E, Table II of our paper, in a regression of Top on Articles, the coefficient on Articles is positive and reliably significant (coefficient $=0.00322,-0.01$ ).

Beside the press visibility proxy, we use industry-adjusted ROA (IndadjROA) for the prior three years under the CEO's tenure as a proxy for CEO talent. In particular, we compute ROA for a firm as income before extraordinary items (Compustat data 18) scaled by average total assets. We delete firms with missing ROA observations and only retain industries where we can find at least 10 firms in a two digit SIC code for a year. We compute the cumulative distribution function (CDF) of ROA for each CEO firm-year by industry and then calculate the three-year rolling average of the CDF rank of ROA. If the same CEO has not been in office for the last three years, we use an average ROA computed over the CEO's tenure. ${ }^{7}$ Higher (lower) ranks suggest that the CEO outperformed (underperformed) the industry. Regressions in panel E of Table II show that Top is positively related to IndadjROA and the association is statistically significant. The positive associations of the two main talent proxies, Articles and IndadjROA, with Top validate these proxies as surrogates for CEO talent. Note that we do not use Top as a 
talent proxy in our empirical tests because Top is an indicator variable and $78 \%$ of the Top observations in the dataset are coded as zero (as shown in panel A of Table II). Thus, Top does not have as much power to detect the presence of the CEO talent effect in the data while Articles and IndadjROA are continuous variables with a reasonable degree of cross-sectional variation and hence greater power to test the talent hypothesis for the lack of RPE. Moreover, Top is likely to be correlated with both Articles and IndadjROA and introducing Top as a talent proxy together with Articles and IndadjROA would deprive these variables of power. ${ }^{8}$

Another observation about the Articles proxy also deserves mention. Untabulated results show that Articles is not highly correlated with our compensation variable, $\Delta$ Total Compensation discussed below in section II.B (correlation $=0.04, p$-value $<0.05$ ) or with IndadjROA (correlation $=0.08, p$-value $<0.01$ ). Thus, the press mentions proxy, Articles, is not merely a transformed version of the compensation or performance variables, devoid of any economic or statistical signal of its own.

\section{B. Compensation data}

The compensation measure used in the empirical tests is the change in the CEO's firmrelated wealth (4Total Compensation) following Aggarwal and Samwick (1999a and b; Himmelberg and Hubbard 2000). The variable, $\Delta$ Total Compensation, is measured as the sum of three components: (i) cash compensation, measured as the sum of salary and bonus and other annual cash payouts for the year; (ii) Black-Scholes value of options granted and the market value of restricted stock granted during the year and other long term incentive payouts; and (iii) change over the year in the market value of equity and options held by the CEO at the beginning of the year. We use equity and option levels held at the beginning of the year to avoid confounding issues introduced by equity sales and option exercises during the year. 
Descriptive data reported in panel B of Table II reveal that the median CEO receives annual salary and bonus of $\$ 795,800$ and $\$ 682,440$ respectively. As is well known, cash compensation is not the major source of incentives provided to top management. The median CEO receives $\$ 1.628$ million in option grants and no restricted stock. The change in market value of equity and options held by the median CEO is $\$ 2.53$ million. Unreported analyses indicate that when the bull market years starting from 1998 are dropped from the sample, the median change in the market value of equity and options drops to $\$ 669,000$.

Note that the mean CEO enjoys a staggering average annual appreciation of $\$ 69.764$ million in his option and stock portfolio. Further analysis reveals considerable right skewness in the data and that most of this appreciation is attributable to the bullish stock market in the year 1999 and to a few CEOs who have large ownership stakes in their firms such as William Gates III of Microsoft, Larry Ellison of Oracle, Michael Dell of Dell Corporation, Scott McNealy of Sun Microsystems and Robert Goizueta of Coca Cola Corporation. The presence of such outliers in the dataset motivates our use of median regressions in the paper (e.g., Aggarwal and Samwick 1999a and b; Milbourn 2003). Panel C provides further evidence on the size of CEO's wealth in their firms. CEO wealth is measured at the start of the year for the purposes of hypothesis testing. The median and mean CEO firm specific wealth is $\$ 28.65$ million and \$237.47 million

Our tests of the outside opportunities hypothesis and RPE rely on cross-sectional variation in the pay-performance sensitivity. We compute dollar returns to shareholders to assess pay-performance sensitivity consistent with several recent papers (Aggarwal and Samwick 1999a, 1999b, Milbourn 2003, Garvey and Milbourn 2003). In particular, we compute three measures of dollar returns: (i) $\Delta$ Shareholder wealth-firm measured as the market value of the 
firm at the beginning of the sample year multiplied by percent returns for the firm, where both the returns and the market value of the firm are extracted from Execucomp; (ii) two market-wide measures of performance where $\Delta$ Shareholder wealth-industry ( $\Delta$ Shareholder wealth-market) is measured as the market value of the firm at the beginning of the sample year multiplied by the percent returns earned by other firms in the two digit SIC code (S\&P 500 market index). In other words, $\Delta$ Shareholder wealth-firm is the realized dollar return to shareholders for a firmyear while $\Delta$ Shareholder wealth-industry ( $\Delta$ Shareholder wealth-market) is the hypothetical dollar return to shareholders if the firm had earned the return offered by the industry (S\&P 500) index. Industry returns and S\&P500 index returns are calculated using CRSP tapes. Note that we use the two measures of market-wide performance, namely the industry and S\&P 500 market index, for our tests because we do not know for sure whether firms benchmark CEO pay to one of these specific indexes. We acknowledge that industry and S\&P 500 could potentially capture different underlying phenomena that are not explicitly modeled or discussed in our paper.

Descriptive data related to these dollar returns are presented in panel C of Table II. The median dollar-return for a firm is $\$ 591.02$ million compared to the median industry-based return of $\$ 626.56$ million and a market-based return of $\$ 232.47$ million. As expected, market basedshareholder returns have a lower standard deviation than firm-or industry-based dollar returns. Panel D reports descriptive data on the variance of shareholder wealth and firm size. As expected, the median firm is large with a market capitalization of $\$ 5.386$ billion. Panel D also provides descriptive data on the governance structure of these firms. Details of the governance data are discussed in subsection III.B.

\section{Empirical specification}

The general empirical specification employed in the paper is as follows: 
$\Delta$ Total CEO Compensation ${ }_{j t}=\beta_{0}+\beta_{1} \Delta$ Shareholder Wealth-Firm ${ }_{j t}+\beta_{2} \Delta$ Shareholder

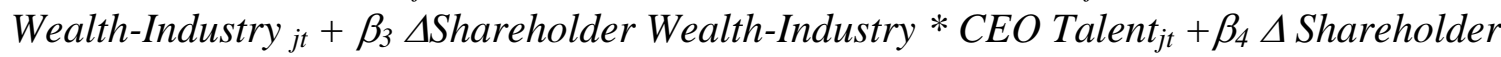
Wealth-Firm * Controls + 2-digit industry dummies ${ }_{j}+$ Year dummies $_{t}+$ error $_{j t}$

Equation (2) is also estimated after substituting the "Market Index" instead of the "Industry Index." In equation (2), $\beta_{1}$ is the pay-for-performance sensitivity (PPS). As noted earlier and consistent with Janikiraman, Lambert and Larcker (1992), if the strong form of RPE holds in the data, we expect $\beta_{2}$ to be negative and equal in magnitude to $\beta_{1}$ (or $\beta_{1}+\beta_{2}=0$ ). However, if the weak form of RPE describes the data, we expect $\beta_{2}$ to be negative but less than $\beta_{1}$ in absolute magnitude. These predictions are consistent with the notion that under the strong (weak) form of RPE, the compensation committee filters out market-wide performance completely (partially) while paying managers. If the talent explanation accounts for why CEOs are not subject to RPE, we expect $\beta_{3}$ to be positive. ${ }^{9}$ Our proxies for CEO talent are Articles and IndadjROA.

Extant research suggests that PPS is a function of CEO age, firm size and variability of dollar returns. Gibbons and Murphy (1992) show that PPS increases with CEO age. Baker and Hall (2000) and Core and Guay (2001) point out that the CEO's marginal product varies with firm size and hence PPS and firm size may be related. Aggarwal and Samwick (1999) report that PPS decreases with the variance in shareholder dollar returns. Consistent with their work, we compute variance of dollar returns for each firm. In particular, we multiply the market value of the firm at the beginning of the sample year with the variance of monthly returns where monthly returns to shareholders are calculated over the sixty months preceding the sample year. We add two-digit industry dummies and year dummies to control for differences in pay-levels across industries and time (Murphy 1999). We also introduce the interaction of $\Delta$ Shareholder WealthIndustry * CEO Tenure as a control variable in the empirical tests. We do not interpret the sign 
on this coefficient because of two conflicting arguments. On one hand, CEOs who have longer tenure are likely more talented and hence they ought to experience lower RPE if our CEO talent hypothesis holds. On the other hand, CEOs with longer tenure are likely to have captured their boards of directors and compensation committees. Hence, absence of RPE, if found, could be indicative of managerial skimming and not necessarily evidence in support of the CEO talent explanation.

Thus, our main empirical specification is as follows:

$$
\begin{aligned}
& \Delta \text { Total CEO Compensation }{ }_{j t}=\beta_{0}+\beta_{1} \Delta \text { Shareholder Wealth (SW)-Firm }{ }_{j t}+\beta_{2} \Delta \text { Shareholder }
\end{aligned}
$$

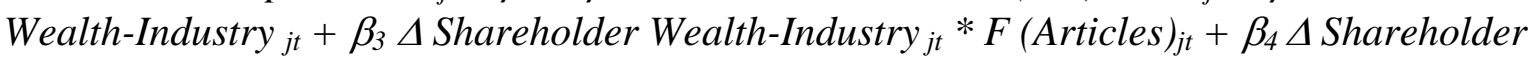

$$
\begin{aligned}
& \text { Wealth-Industry }{ }_{j t} * \text { IndadjROA }_{j t}+\beta_{5} \Delta \text { Shareholder Wealth-Industry }{ }_{j t} * F(C E O \text { Tenure })_{j t} \\
& +\beta_{6} \Delta \text { Shareholder Wealth-Firm }{ }_{j t} * F(\text { Size })_{j t}+\beta_{7} \Delta \text { Shareholder Wealth-Firm }{ }_{j t} * F(\text { Size })_{j t} \\
& +\beta_{8} \Delta \text { Shareholder Wealth-Firm }{ }_{j t}^{*} F(\text { Variance of shareholder wealth) })_{j t}+2 \text {-digit industry } \\
& \text { dummies }_{j}+\text { Year dummies }_{t}+\text { error }_{j t}
\end{aligned}
$$

As indicated before, equation (3) is also estimated after substituting the "Market Index" in place of the "Industry Index." To facilitate intuitive interpretation of the economic significance of results, we follow Aggarwal and Samwick (1999) and construct the cumulative distribution functions (CDFs) of certain empirical variables. In particular, any variable on which the sensitivity to dollar returns depends is first normalized according to its empirical CDF and then interacted with the appropriate dollar returns variable. ${ }^{10}$ Normalizing the interactive raw variables to the unit interval enables ease of interpretation and reduces the impact of extreme outliers on the regression specification. To illustrate, the estimated pay-for market-wide performance for a given level of $\Delta$ Shareholder wealth-Industry, conditioned on Articles, is $\beta_{2}+$ $\beta_{3} F$ (Articles) where $F($.$) refers to the CDF of articles. Thus, the range of coefficients is \beta_{2}$ for the $\mathrm{CEO}$ with the least number of media cites and $\beta_{2}+\beta_{3}$ for the CEO with the most number of media cites. The coefficients related to the CEO with the median number of media cites is $\beta_{2}+$ 
$0.5 \beta_{3}$. If the CEO talent explanation for the lack of RPE is descriptive of the data, we expect positive coefficients on the interaction between pay for market or industry-wide movements and the CEO talent proxies i.e., $\beta_{3}$ and $\beta_{4}$. Note that IndadjROA is inherently a rank measure, as described earlier, and hence is not expressed as a CDF.

Another important methodological issue is that all specifications in the paper are estimated using median regressions. The median is more robust than the mean to the presence of large outliers. Median regressions minimize the sum of absolute deviations rather than the sum of squared deviations. Moreover, because the median is also a more robust estimate of central tendency than the mean, the precision of estimates from a median regression is also higher. In untabulated sensitivity tests, we re-estimate all regressions using Ordinary Least Squares (OLS) with and without winsorizing the data at the $1 \%$ and the $99 \%$ level. Unreported results of the OLS regressions after winsorization yield inferences similar to the reported median regressions but the results without winsorization are different. Moreover, consistent with the considerable right skewness of the $\Delta$ Total Compensation data, the PPS estimates using the median regressions are much smaller than those obtained via OLS. ${ }^{11}$

Results of estimating equation (3) are presented in Table III. Columns (1) and (2) assess the existence of RPE with respect to the industry index and the market-wide S\&P 500 index, respectively. As mentioned before, we report results only for the most restrictive sample of 2,343 CEO firm-years where Articles and IndadjROA are both available. We reiterate that untabulated analyses confirm that all the inferences reported in the paper apply to the larger sample of 3,487 CEO-firm years for which usable data on Articles exists.

[INSERT TABLE III HERE] 
Column (1) shows that the estimated PPS for a CEO in our sample with minimum $F$ (Articles) and IndadjROA is $\$ 8.00$ for a thousand dollar increase in the market value of the firm. These estimates are much larger than the $\$ 3.25$ per $\$ 1,000$ increase in shareholder wealth estimated by Jensen and Murphy (1990). When we estimate the reduced model in column (1) with only two terms $\Delta$ Shareholder Wealth-Firm jt $_{\text {and }} \Delta$ Shareholder Wealth-Industry (and industry and year controls), we find that the estimated PPS is $\$ 3.24$ per $\$ 1,000$. Thus, consistent with prior work (e.g., Aggarwal and Samwick 1999a, Himmelberg and Hubbard 2000), PPS estimates tend to be higher when controls for variance of shareholder wealth, size and age are introduced.

In column (1), the coefficient on $\Delta$ Shareholder Wealth-Industry is -2.36 while the sum of the coefficients on $\Delta$ Shareholder Wealth-Firm and $\Delta$ Shareholder Wealth-Industry is not equal to zero $(15.82-2.36$, $p$-value $=0.00)$, suggesting evidence in favor of the weak form of RPE. Of particular interest is the finding that the extent of RPE falls with Articles and IndadjROA in column (1), our proxies for the $\mathrm{CEO}$ talent, consistent with $\mathrm{H} 1$.

The panel at the bottom of Table III reports PPS evaluated at median values of talent and control variables. For example, median PPS is $\$ 8.70$ per $\$ 1,000$ increase in shareholder wealth under column (1). This PPS is computed by evaluating the coefficients of the regression at median values of the CDFs of the independent variables. To derive PPS at the minimum and maximum values of the talent variables, we retain all variables at median values, except for $F$ (Articles) and IndadjROA which are varied to assume minimum and maximum values. The objective is to assess the effect on PPS, including the effect of benchmarking, for executives with various ranges of talent. For example, we observe that the sensitivity of pay to the industry index for a CEO with median Articles and IndadjROA under column (1), our proxies for talent, is 
$\$ 8.70$ and that sensitivity ranges from $\$ 8.00$ for a CEO with minimum Articles and IndadjROA to $\$ 9.25$ for a CEO with maximum Articles and IndadjROA.

A similar picture emerges from column (2) where the proxy for peer performance is the S\&P 500 market index. The coefficient on 4 Shareholder Wealth-Market Index in column (2) is -6.83 and the sum of the coefficients on $\Delta$ Shareholder Wealth-Firm and $\Delta$ Shareholder WealthMarket index is reliably different from zero $(14.30-6.83, p$-value $=0.00)$, consistent with weak form RPE. Note that the magnitude of the coefficient on $\Delta$ Shareholder Wealth-Market index $(-6.83)$ is larger than the magnitude of the coefficient on $\Delta$ Shareholder Wealth-Industry index (-2.36), consistent with Gibbons and Murphy (1990).

As before, the extent of RPE diminishes with proxies for CEO talent, Articles and IndadjROA. In fact, as shown in the lower panel in the table corresponding to column (2), the spread in the absence of RPE due to talent proxies is higher when market index is the peer performance measure used. We observe that the sensitivity of pay to the market index for a CEO with median Articles and IndadjROA is $\$ 7.66$ and that sensitivity ranges from $\$ 4.58$ for a CEO with minimum Articles and IndadjROA to $\$ 9.56$ for a CEO with maximum Articles and IndadjROA. ${ }^{12}$ Thus, the range of extreme PPS values, scaled by the median talented CEO's PPS is reasonably large, varying from $59.8 \%(\$ 4.58 / \$ 7.66)$ to $124.8 \%(\$ 9.56 / \$ 7.66)$. This reasonably wide range suggests that the impact of CEO talent on the absence of RPE is likely to be economically significant. Thus, the empirical evidence is consistent with the argument that absence of RPE is positively related to CEO talent.

Incidentally, it is interesting to note that CEOs with higher tenure have lower RPE in their compensation contracts. However, assigning an unambiguous interpretation to this finding is difficult, as discussed earlier. Turning to the control variables, PPS falls with firm size and 
CEO age, but contrary to prior work (Aggarwal and Samwick 1999a), PPS appears to increase with variance of shareholder returns in our sample. ${ }^{13}$ In summary, the evidence presented in Table III is consistent with Oyer (2004) and Himmelberg and Hubbard (2000)'s theory that RPE is optimally lower for talented CEOs.

\section{Alternate explanations}

\section{A. CEO talent and PPS}

Milbourn (2003) finds that the CEO's talent, also proxied by a count of media cites for the CEO, is related to the observed pay-for-performance sensitivity (PPS). Although his paper addresses a different research question (the link between CEO talent and PPS) from ours (the link between CEO talent and the absence of RPE), one can ask whether the empirical relation between the proxy for CEO talent and the absence of RPE that we document in Table III is incremental to Milbourn's findings. To address that concern, we interact our proxies for the CEO talent (Articles and IndadjROA) with both (i) $\Delta$ Shareholder Wealth-Firm (PPS); and (ii) AShareholder Wealth-Industry (Market) (RPE) and introduce these interaction terms simultaneously in an abridged version of equation (2) and estimate the resultant specification. Results reported in Table IV show that the interactions of CEO talent proxies with either AShareholder Wealth-Industry or 4 Shareholder Wealth-Market are positive and statistically significant in three out of four cases (columns 1, 3 and 4), consistent with less RPE for talented CEOs. We are also able to replicate Milbourn's findings that the PPS increases with CEO talent as coefficients on the interaction of $\Delta$ Shareholder Wealth-Firm and CEO talent are positive and significant in all cases. Thus, results in Table IV assure us that the interaction of CEO talent and RPE is a different empirical phenomenon from the one documented by Milbourn. ${ }^{14}$

[INSERT TABLE IV HERE] 


\section{B. Skimming explanation}

The empirical results in Table III show that CEOs who are more talented are paid more when the performance of the industry or market index is good. However, corporate governance activists have claimed that this result may be consistent with rent-extraction by CEOs who exploit lax governance mechanisms. Bertrand and Mullainathan (2001) suggest that departures from RPE are pure rents to CEOs. We investigate whether the sensitivity of pay for market or industry-wide performance is indeed a manifestation of such pure rents by including proxies for the quality of corporate governance in the model in equation (3). In particular, we introduce interactions between $\Delta$ Shareholder Wealth-Industry (or $\Delta$ Shareholder Wealth-Market), and five governance proxies: (i) $g$ score - a measure of shareholder rights - compiled by Gompers, Ishii and Metrick (2003) where a larger (smaller) $g$ score indicates less (more) bargaining power for the shareholder vis-à-vis the manager; (ii) a dummy variable, CEO-Chair, that is set to one if the chairman of the board is the CEO and zero otherwise as per Execucomp; (iii) the proportion of the executive team that serves on the board, Onboard as per Execucomp; (iv) the proportion of the executive team subject to an interlocked relation (Interlock) as per Execucomp; ${ }^{15}$ and (v) Meetings, the number of board meetings held during the year as per Execucomp. Greater values of the first four proxies and smaller number of Meetings are assumed to indicate poor governance. If the skimming explanation accounts for our results, we would expect the interaction of $\Delta$ Shareholder Wealth-Industry (or AShareholder Wealth-Market) and the governance proxies to indicate less RPE in the presence of poor governance. More important, if the skimming explanation were to dominate the CEO talent explanation, the coefficients on the interaction of $\Delta$ Shareholder Wealth-Industry (or AShareholder Wealth-Market) and the CEO talent proxies ought to be zero. 
Panel D of Table II reports descriptive data on the governance proxies used in this paper. To conserve sample size, we set missing $g$ scores to zero. We obtain a $g$ score for $90 \%$ of the firm-years, indicated by the dummy variable $D_{g}$ score, that is set equal to one (zero) when we have (do not have) a $g$ score. CEO is also the chair of the board $86 \%$ of the time. Approximately $34 \%$ of the executive team serves on the board while $1 \%$ of the executive team is subject to an interlocked relation. The board meets seven times a year in the median firm. In untabulated analyses, we find that our talent proxies are not highly correlated with the governance variables. In fact none of the correlations between either Articles or IndadjROA with the corporate governance variables exceeds $|0.18|$ suggesting that the CEO talent and RPE results are not likely due to governance issues.

Results of regressions after introducing the governance terms are reported in Table V. These results suggest mixed evidence in support of the skimming hypothesis. We observe less RPE when the CEO is also the chair of the board and when the board holds fewer meetings in a year in both the specifications reported in the table, consistent with skimming. The results are somewhat mixed across the two columns when the interaction of the index and (i) Onboard; and (ii) Interlock are considered. Most important, however, the CEO talent explanation for the lack of RPE for talented managers survives the skimming explanation. In particular, the coefficients on the interaction of $\Delta$ Shareholder Wealth-Industry (or $\Delta$ Shareholder Wealth -Market) and the CEO talent proxies are positive and significant in both specifications. To point to one case, the sensitivity of pay to the market index for a CEO for CEOs with minimum and maximum Articles and IndadjROA ranges from $\$ 5.59$ to $\$ 12.04$ as per column (2).

[INSERT TABLE V HERE]

\section{Oligopolistic industries}


Aggarwal and Samwick (1999) suggest that the absence of RPE is driven by strategic interaction among firms in the product markets. In particular, as in RPE, a negative weight on the rival firm's performance in compensating managers might create incentives for managers to compete too aggressively in the product market and thus hurt the firm's profitability. Thus, in highly concentrated industries, lower emphasis on RPE may be optimal to avoid excessive competition among rival managers and hence to maximize joint (industry-wide) returns. To assess whether that explanation could affect our results, we compute the Herfindahl-Hirschman Index and interact such index with market-wide or industry-wide performance. The HerfindahlHirschman index (HHI) is equal to the sum of an industry's (two-digit SIC) squared market shares (in percentages). Following Defond and Park (1999), the HHI value assigned to each sample year equals its industry-average $H H I$ over the five years prior to the event year. High (low) levels of $\mathrm{HHI}$ imply high (low) industry concentration and high competition. We interact HHI with $\Delta$ Shareholder Wealth-Industry (or $\Delta$ Shareholder wealth-Market) and introduce the resultant interaction term in equation (3). ${ }^{16}$ This interaction term would assume a positive coefficient if it were optimal to soften RPE incentives in concentrated industries. Moreover, if our results are driven by strategic interplay in product markets, then the associations between pay for market-wide or industry-wide performance and CEO-talent ought to disappear. A priori, we do not expect our Table III results to be substantially affected by the introduction of the HHI interaction because the (untabulated) correlation between $\mathrm{HHI}$ and the CEO talent proxies is not statistically significant. None of the results reported in Table VI are consistent with the hypothesis of less RPE in oligopolistic industries. As expected, the inclusion of these $\mathrm{HHI}$ based interactions has virtually no effect on the CEO talent interactions.

[INSERT TABLE VI HERE]

\section{Firm level hedging}


Garvey and Milbourn (2003) argue that compensation committees do not filter out market-wide changes from executive compensation (i.e., the absence of RPE) because executives can filter out such changes on their own by accessing the capital market. In particular, they argue that younger executives and those with smaller firm-specific wealth (which is a proxy for the CEO's unobservable total wealth) cannot undo the filtering of market effects easily. Hence, the sensitivity of their pay to market-wide factors would be smaller - that is, these executives will face more RPE than older executives and those with more firm-specific wealth. To assess the robustness of our results to this explanation, we interact $\Delta$ Shareholder Wealth-Industry (or $\Delta$ Shareholder Wealth-Market) with two variables: (i) CEO age; and (ii) the level of firm-specific wealth held by the CEO at the beginning of the year. We introduce these interaction terms into equation (3) and investigate whether the coefficients on $\Delta$ Shareholder wealth-Industry and CEO-talent proxies are still positive and significant. Results reported in Table VII indicate mixed support for the hedging explanation as the interaction of industry and market indexes and the level of CEO wealth is positive and significant while the interaction of the indexes with CEO age is negative and significant throughout. These results suggest that CEOs with more firmspecific wealth face less RPE, consistent with the hedging explanation. However, inconsistent with the Garvey and Milbourn (2003) hypothesis, older CEOs in our sample face more RPE.

\section{[INSERT TABLE VII HERE]}

More importantly, the interaction of the industry and market indexes with the Articles based proxy for CEO talent continues to be positive and significant for the industry index but is positive and insignificant for the market index. In untabulated results, we find that the interaction of Articles and market index is positive and statistically significant (coefficient $=$ $0.68, p$-value $<0.01$ ) when the larger sample of 3,487 observations with usable Articles 
observations is used. However, the interaction of the market index and IndadjROA is negative in column (1) and insignificant in column (2). Further investigation reveals that the lowest correlation between the interaction of any index and F(firm specific wealth at the start of the year) and the interaction of that index and IndadjROA is 0.94 ( $p$-value $<0.01$ ). Hence, disentangling the CEO talent explanation from the hedging hypothesis is difficult when IndadjROA is the talent proxy. However, when Articles is the talent proxy, the CEO talent explanation still generally stands.

\section{E. Asymmetric benchmarking}

Bertrand and Mullainathan (2001) and Garvey and Milbourn (2004) note that CEO pay is benchmarked to the market index only when the market seems to be up. In other words, CEO pay is shielded from bad luck (or negative exogenous shocks) but is sensitive to good luck (positive exogenous shocks). The authors characterize these findings as evidence of rent extraction by managers. It is ambiguous whether the retention explanation proposed by Oyer (2004) and Himmelberg and Hubbard (2000) is symmetric with respect to the up and the down market - is a talented CEO's pay as exposed to the down market as it is in the up market?

In contrast to Bertrand and Mullainathan (2001) and Garvey and Milbourn (2004)'s thesis that asymmetric benchmarking indicates rent extraction by managers, one can posit at least three conceptual arguments for why shielding talented CEOs in a down market downturn might be optimal from the firm's perspective. First, more talented CEOs would continue to have greater outside opportunities in a bad market relative to less talented CEOs. Moreover, they can pursue opportunities in the not-for-profit sector or they may decide to take time off during a downturn to write a memoir or pursue other personal interests. In fact, retaining talented executives in a market downturn might be even more important for the firm than retaining them in an up market. 
Second, firms often weed out less talented managers in a bad market as it is relatively easy to hire away talented managers from rival firms. Hence, firms with talented managers have to be even more careful to not lose such managers in a bad market. Third, shielding pay of talented managers in a down market has the same economic flavor as repricing stock options in a down market. Several researchers have argued that option repricing might be optimal (e.g., Saly 1994; Acharya, John and Sundaram 2000; Carter and Lynch 2001 and 2004; and Chidambaram and Prabhala 2003).

To explore whether asymmetric benchmarking occurs, especially for talented executives, we separate the sample into an up (down) sample depending on whether the industry index or the S\&P 500 market index records negative (non-negative) buy-and hold annual returns. For the up and down sub-samples, we estimate the basic equation (3) and present the results related to the up (down) markets in panels A (B) of Table VIII. Results reported in panel A are very similar to those reported in Table III in that talented managers are subject to less relative performance evaluation in an up market. Turning to the down market results in panel $\mathrm{B}$, we find that the coefficient on $\Delta$ Shareholder Wealth-Industry is negative and significant while the one on $\Delta$ Shareholder Wealth-Market is negative but insignificant, suggesting that firms generally shield CEO pay from an industry but not a market downturn. However, the sign on the interaction of AShareholder Wealth-Industry (or $\Delta$ Shareholder Wealth-Market) and F(Articles) is mixed. Note that in column (2), the sign $\Delta$ Shareholder Wealth-Market ${ }^{*} F$ (Articles) is negative, suggesting that talented executives are shielded more in a downturn while in column (1), the sign on the interaction term $\Delta$ Shareholder Wealth-Industry * F(Articles) is positive suggesting that talented executives are shielded less in a downturn. Further, the coefficient on $\Delta$ Shareholder Wealth-Industry (or $\triangle$ Shareholder Wealth-Market) and IndadjROA is also mixed - positive in 
column (1) and insignificant in column (2). Hence, the results reveal no systematic pattern of asymmetric benchmarking for either talented or untalented executives to suggest that rent extraction is the dominant explanation for asymmetric benchmarking.

[INSERT TABLE VIII HERE]

\section{Conclusions}

A widespread concern among both practitioners and academics is that executive pay lacks relative performance evaluation (RPE). In recent years, significant increases in CEO compensation concurrent with the bull markets have prompted several critics to argue that CEO's compensation for market-wide shocks is windfall pay consistent with systematic governance failures. A few economists (Oyer 2004 and Himmelberg and Hubbard 2000) have proposed that what looks like windfall pay might reflect the special conditions in the labor markets for CEOs. If CEO talent is scarce, then the supply of talented CEOs is relatively inelastic. Under such conditions it may be optimal to reward CEOs for market-wide shocks if such shocks raise the firm's market value and the CEO's outside employment opportunities. Empirical testing of this hypothesis is hampered by the absence of readily available proxies for CEO talent.

We contribute in this regard by constructing proxies for CEO talent based on the CEOs' visibility in the financial press and the CEO firm's past industry-adjusted ROA. Relying on emerging research (Milbourn 2003 and Francis et al. 2004) and our own work, we validate the press visibility proxy in several ways. Our empirical results based on these proxies show that the absence of RPE is systematically related to CEO's talent. These results are robust to several checks against alternate hypotheses such as skimming and strategic consideration in oligopolistic industries. We observe asymmetric benchmarking (less RPE when the market is up but more 
RPE when the market is down) but there is no systematic pattern of asymmetric benchmarking for talented executives to suggest that rent extraction is the dominant explanation. Taken together, we believe our results are consistent with the CEO talent explanation for the relative absence of RPE in executive compensation contracts. 


\section{References}

Abowd, John M., and David S. Kaplan, 1999, Executive compensation: six questions that need answering, Journal of Economic Perspectives 13, 145-68.

Acharya, Viral V., Kose John and Rangarajan K. Sundaram, 2000, On the optimality of resetting executive stock options, Journal of Financial Economics 57(1), 65-101.

Aggarwal, Rajesh K., and Andrew A. Samwick, 1999a, The other side of the trade-off: The impact of risk on executive compensation, The Journal of Political Economy 107(1), 65-105.

Aggarwal, Rajesh K., and Andrew A. Samwick. 1999b, Executive compensation, strategic competition, and relative performance evaluation: Theory and evidence, The Journal of Finance. 54(6), 1999-2043.

Antle, Rick, and Abbie Smith, 1986, An empirical investigation of the relative performance evaluation of corporate executives, Journal of Accounting Research 24, 1-39.

Baiman, Stanley, and Joel S. Demski, 1980, Economically optimal performance evaluation and control systems, Journal of Accounting Research 18, 184.

Baker, George P., and Brian J. Hall, 2000, CEO incentives and firm size, Working Paper no. 6868, National Bureau of Economic Research. 
Barro, Jason R. and Robert J. Barro, 1990, Pay, performance, and turnover of bank CEOs, Journal of Labor Economics 8(4), 448-481.

Bebchuk, Lucian.A., Jesse M. Fried, and David I. Walker, 2002, Managerial power and rent extraction in the design of executive compensation, The University of Chicago Law Review 69, 751-846.

Bebchuk, Lucian.A., and Jesse M. Fried, 2003, Executive compensation as an agency problem, Journal of Economic Perspectives 17(3), 71-92.

Bertrand, Marianne, and Sendhi Mullainathan, 2001, Are CEOs rewarded for luck? The ones without principals are, The Quarterly Journal of Economics 116(3), 901-931.

Carter, Mary Ellen, and Luann J. Lynch, 2001, An examination of executive stock option repricing, Journal of Financial Economics 61(2), 207-225.

Carter, Mary Ellen, and Luann J. Lynch, 2004, The effect of stock option repricing on employee Turnover, Journal of Accounting and Economics 37, 91-112.

Chidambaran, N.K., and Nagpurnanand.R. Prabhala, 2003, Executive stock option repricing, internal governance mechanisms, and management turnover, Journal of Financial Economics 69(1), 153-189 
Core, John, and Wayne Guay, 2001, The other side of the tradeoff- a comment. Unpublished manuscript, Wharton School, University of Pennsylvania.

Crystal, Graef S., 1991, In Search of Excess. The Overcompensation of American Executives (New York, W.W. Norton).

Defond, Mark L., and Chul W. Park, 1999, The effect of competition on CEO turnover, Journal of Accounting and Economics 27(1), 35-56.

Diamond, Douglas W., and Robert E. Verrecchia, 1982, Optimal managerial contracts and equilibrium security prices, Journal of Finance May, 275-87.

Francis, Jennifer, Allen H. Huang, Shivaram Rajgopal and Amy Y. Zang, 2004, CEO reputation and reporting quality, Unpublished manuscript, Duke University and University of Washington.

Garvey, Gerald and Todd Milbourn, 2003, Incentive compensation when executives can hedge the market: Evidence of RPE in the cross-section, Journal of Finance 58, 1557-1581.

Garvey, Gerald and Todd. Milbourn, 2004, Asymmetric benchmarking in compensation: Executives are rewarded for good luck but not penalized for bad, Journal of Financial Economics (forthcoming). 
Gibbons, Robert and Kevin J. Murphy, 1990, Relative performance evaluation for chief executive officers, Industrial and Labor Relations Review 43, 30-51.

Gibbons, Robert and Kevin J. Murphy, 1992, Optimal incentive contracts in the presence of career Concerns: Theory and evidence, Journal of Political Economy 100(3), 468-505.

Gompers, Paul A., Joy L. Ishii and Andrew Metrick, 2003, Corporate Governance and Stock Prices, Quarterly Journal of Economics (forthcoming).

Himmelberg, Charles, and R. Glenn Hubbard, 2000, Incentive pay and market for CEOs: an analysis of pay-for-performance sensitivity, Unpublished manuscript, Columbia University.

Holmstrom, Bengt, 1979, Moral hazard and observability, Bell Journal of Economics 10, 79-41.

Holmstrom, Bengt, 1982, Moral hazard in teams, Bell Journal of Economics 13, 324-40.

Janakiraman, Surya., Richard A. Lambert and David F. Larcker, 1992, An empirical investigation of the relative performance evaluation hypothesis, Journal of Accounting Research $30(1), 53-69$.

Jensen, Michael, and Kevin J. Murphy, 1990, Performance pay and top-management incentives. Journal of Political Economy 98, 225-264. 
Milbourn. Todd, 2003, CEO reputation and stock-based compensation, Journal of Financial Economics 68-2, 233-262.

Murphy, Kevin J., 1985, Corporate performance and managerial remuneration: an empirical analysis, Journal of Accounting and Economics 7, 11-42.

Murphy, Kevin J., and Jerry Zimmerman, 1993, Financial performance surrounding CEO turnover, Journal of Accounting and Economics 16(1-3), 273-315.

Murphy, Kevin J., 1999, Executive Compensation. In O. Ashenfleter and D. Card, eds., Handbook of Labor Economics. Vol. 3 (Amsterdam: North-Holland).

Oyer, Paul, 2004, Why do firms use incentives that have no incentive effects? The Journal of Finance 59, 1619-1649.

Pourciau, Susan, 1993, Earnings management and nonroutine executive changes, Journal of Accounting and Economics 16(1-3), 317-336.

Prendergast, Canice, 1999, The provision of incentives in firms, Journal of Economic Literature $37,7-63$.

Rappaport, Alfred, 1999, New thinking on how to link executive pay with performance, Harvard Business Review 77, 91-101 
Rosen, Sherwin, 1982, Authority, control and the distribution of earnings, Bell Journal of Economics 13, 311-323.

Saly, P. Jane, 1994, Repricing executive stock options in a down market, Journal of Accounting and Economics 18, 325-356.

Sloan, Richard G., 1993, Accounting earnings and top executive compensation, Journal of Accounting and Economics 16(1-3), 55-100.

Weisbach, Michael S., 1988, Outside directors and CEO turnover, Journal of Financial Economics 20(1,2), 431-460. 


\section{Table I \\ Sample Selection}

The initial sample of 464 firms and 3,487 CEO-firm years with data on press mentions of CEOs (Articles below) consists of officers named as CEOs of all S\&P 500 companies during the period 1993 to 2001 in the Execucomp database after eliminating firms with missing firm-level data from Compustat and monthly stock return data from CRSP. The final sample of 403 firms and 2,343 CEO-firm years with data on both Articles and industry-adjusted average ROA over the last three years (IndadjROA below) consists of those observations wherein return on assets can be computed over the same CEO's tenure after eliminating CEO firm-years with missing CEO-level data from Execucomp and return data from CRSP.

\begin{tabular}{lrr}
\hline & Firms & CEO-years \\
\hline 1993 to 2001 Execucomp firm-years with non-missing data for S\&P & & \\
500 firms and top 5 executives & 513 & 28,250 \\
Less: non-CEO Executives & 13 & 24,356 \\
Less: missing Compustat data & 25 & 280 \\
Less: missing CRSP data & 11 & 127 \\
Initial sample with data on Articles & 464 & 3,487 \\
\hline Less: Firm-years in industry-years with $<10$ firms & & 30 \\
Less: non-incumbent CEO-firm years & & 855 \\
Less: missing Execucomp data & & 186 \\
Less: missing other CRSP data & & 73 \\
Final Sample with data on both Articles and IndadjROA & 403 & 2,343 \\
\hline
\end{tabular}




\section{Table II}

\section{Descriptive Statistics}

The table presents descriptive statistics for the final sample of 403 firms and 2,343 CEO-firm years with data on both press mentions of CEOs (Articles below) and industry-adjusted average ROA over the last three years (IndadjROA below) and consists of officers named as CEOs of all S\&P 500 companies during the period 1993 to 2001 in the Execucomp database after eliminating CEO firm-years with missing data from Compustat and CRSP. The table presents the mean, standard deviation and median for all variables including the talent proxies in Panel A, compensation data in thousand dollars in Panel B, wealth data in million dollars in Panel $\mathrm{C}$ and control and other variables in Panel D. Panel E presents OLS regression results to validate the CEO talent proxies. The dependent variable is the indicator variable Top, which is coded as one if the CEO is recognized as a top manager in lists published by the financial press. The independent variables are IndadjROA and the empirical cumulative distribution function (CDF) for Articles and Size (market value of equity). The first column of Panel E uses 3,487 CEO-firm year observations with data on Articles. The second and third column of Panel E uses 2,343 CEO-firm year observations with data on both Articles and IndadjROA. Sources and computations for all variables are described at the end of the table.

Panel A: Talent Proxies

$N=2,343$

\begin{tabular}{lrrr}
\hline Variables & Mean & Std. dev. & Median \\
\hline Articles & 17.81 & 28.40 & 11.00 \\
Top & 0.22 & 0.41 & 0.00 \\
IndadjROA & 0.68 & 0.20 & 0.70 \\
\hline
\end{tabular}

Panel B: Compensation Data (\$ thousands)

$N=2,343$

\begin{tabular}{lrrr}
\hline Variables & Mean & Std. dev. & Median \\
\hline Salary & 816.75 & 370.94 & 795.80 \\
Bonus & $1,098.74$ & $1,713.40$ & 682.44 \\
Other annual payments & 62.01 & 229.36 & 0.00 \\
Option grants (Black-Scholes) & $5,617.47$ & $20,460.92$ & $1,628.22$ \\
Restricted stock grants & 880.43 & $13,667.83$ & 0.00 \\
Long term incentive payments & 413.64 & $1,709.91$ & 0.00 \\
Other long term compensation & 298.33 & $2,887.85$ & 51.96 \\
Total Flow compensation & $9,187.38$ & $25,580.40$ & $4,283.36$ \\
$\Delta$ Market value of stock & $65,411.13$ & $1,429,771.55$ & 904.91 \\
$\Delta$ Market value of options & $4,353.42$ & $87,167.45$ & 609.23 \\
$\Delta$ Market value of stock and options & $69,764.54$ & $1,474,862.21$ & $2,530.54$ \\
$\Delta$ Total compensation & $78,951.92$ & $1,477,389.64$ & $7,609.44$ \\
\hline
\end{tabular}


Table II -- Continued

Panel C: Wealth Data (\$ millions)

$N=2,343$

\begin{tabular}{lrrr}
\hline Variables & Mean & Std. dev. & Median \\
\hline CEO firm specific wealth at the start of the year & 237.47 & $1,863.32$ & 28.65 \\
$\Delta$ SW - firm & $2,309.50$ & $16,556.61$ & 591.02 \\
$\Delta$ SW - industry & $1,902.89$ & $11,305.53$ & 626.56 \\
$\Delta$ SW - market & 333.17 & $2,857.21$ & 232.47 \\
\hline
\end{tabular}

Panel D: Other Variables

$N=2,343$

\begin{tabular}{lrrr}
\hline Variables & Mean & Std. dev. & Median \\
\hline Size $(\$ m i l)$ & $13,779.19$ & $30,252.50$ & $5,386.66$ \\
CEO age & 57.82 & 6.25 & 58.00 \\
Variance of SW (\$mil) & 104.23 & 301.35 & 34.38 \\
Tenure & 9.39 & 6.86 & 7.43 \\
Governance Variables & & & \\
$\mathrm{D}_{\text {gscore }}$ & 0.90 & 0.31 & 1.00 \\
$\mathrm{D}_{\text {gscore }}$ g score & 8.54 & 3.90 & 9.00 \\
CEO-Chair & 0.86 & 0.35 & 1.00 \\
Onboard & 0.34 & 0.19 & 0.29 \\
Interlock & 0.01 & 0.05 & 0.00 \\
Meetings & 7.33 & 2.82 & 7.00 \\
Herfindahl-Hierschman Index & 0.20 & 0.15 & 0.15 \\
\hline
\end{tabular}

Panel E: Validation of Talent Proxies

\begin{tabular}{|c|c|c|c|}
\hline Variables & Top & Top & Top \\
\hline Intercept & $144.93 \times 10 \mathrm{e}-3^{*}$ & $86.19 \times 10 \mathrm{e}-3 \dagger$ & $61.85 \times 10 \mathrm{e}-3 \dagger$ \\
\hline $\mathrm{F}$ (Articles) & $3.22 \times 10 \mathrm{e}-3^{*}$ & & $2.07 \times 10 \mathrm{e}-3 *$ \\
\hline IndadjROA & & $190.21 \times 10 \mathrm{e}-3 \dagger$ & $89.22 \times 10 \mathrm{e}-3 \dagger$ \\
\hline $\mathrm{F}($ Size $)$ & & & $0.00 \times 10 \mathrm{e}-3 *$ \\
\hline $\bar{N}$ & 3,487 & 2,343 & 2,343 \\
\hline Adjusted $\mathrm{R}^{2}$ & 0.066 & 0.008 & 0.151 \\
\hline
\end{tabular}

Note: $* / \uparrow / \#$ represents statistical significance at the $p$-value $<0.1,0.05,0.10$, respectively and two-tailed. 


\section{Table II -- Continued}

Variable definitions are as follows:

Articles

Top

IndadjROA

Salary, Bonus, and Other annual payments

Option grants

Restricted stock grants, Long term incentive payments, and Other long term

compensation

Total flow compensation

$\Delta$ Market value of stock

$\Delta$ Market value of options

$\Delta$ Total compensation

CEO firm specific wealth at the start of the year

$\Delta \mathrm{SW}$ - firm, industry, market

Size (MVE)

CEO age

Variance of SW

Tenure

$\mathrm{D}_{\text {gscore }}$

$\mathrm{D}_{\text {gscore }} *$ g score

CEO-Chair

Onboard

Interlock

Meetings

Herfindahl-Hirschman Index the number of articles containing the CEO's name and company affiliation that appear in the major U.S. and global business newspapers and newswires in year preceding the fiscal year. An article is included only once irrespective of how many times the CEO's name appears in the article

1 if the CEO is recognized as a top manager in any one of the following lists: Business Week's list of "The Best Managers" (available for 1992 to 2001); Worth's list of the "The Best CEOs" (available for 1998 to 2001); the Financial Times' list of the "World's Most Respected Business Leaders" (available for 1997 to 2001), Time's list of "The Time/CNN 25 Most Influential" (available for 2001) and Fortune's lists of the "The 50 Most Powerful Women in Business" (available for 1998 to 2001) and the "Most Powerful Black Executives in America" (available for 2001), and zero otherwise average of the empirical CDF of within industry-year rankings for the prior three years Execucomp data SALARY, BONUS, and OTHANN, respectively, for the fiscal year estimated grant date value of options granted during the year using a modified version of the Black-Scholes (1973) model. The exercise price, stock price at the grant date, and the number of securities granted, and the time to maturity are obtained from Execucomp. Risk-free rate of interest is the approximate average yield in the data year from a seven-year U.S. Treasury bond. Expected stock return volatility is estimated as the annualized standard deviation of daily stock returns over the 120 trading days preceding the end of the fiscal year of the option grant. Execucomp data RSTKGRNT, LTIP and ALLOTHTOT, respectively, for the fiscal year

sum of salary, bonus, other annual payments, option grants, restricted stock grants, long term incentive payments, other long term compensation

number of shares held by the CEO at the start of the year (including restricted stock) multiplied by the stock return (including dividends) during the year

number of options held by the CEO at the start of the year, multiplied by an estimate of the change in the average option value price during the year. The average option value is estimated based on the method presented by Core and Guay (2002a), except that the time to exercise is equal to $70 \%$ of the Core and Guay assumed time to maturity, and the value at the start (end) of the year is based on the start (end) of the year stock price, as adjusted for stock splits during the data year. All other parameters used are as described for new option grants above. sum of total flow compensation, $\Delta$ Market value of stock, $\Delta$ Market value of options

sum of beginning of the year stock and options. Beginning of the year stock (option) values where the number of shares (options) held by the CEO at the start of the year is valued at the (option values) or share price as of the beginning of the year.

change in shareholder wealth (i.e., beginning of the year market value) multiplied by the firm's return, industry index return and market index return, respectively

number of common stock outstanding times the stock price at the beginning of the fiscal year

CEO's age in the data year

beginning of the year market value times the variance of monthly stock returns, expressed in decimal form (not percentage), over the 60 months preceding the data year.

number of years the CEO has held the top ranking position in the firm

1 if a firm's g score exists in the list from Gompers, Ishii and Metrick (2001), and zero otherwise

$D_{\text {gscore }}$ multiplied by the $\mathrm{g}$ score. $\mathrm{G}$ score is a measure of shareholder power

1 if the CEO is also the chairman of the board, and zero otherwise

proportion of the top five officers that serves on the board calculated as the average of cases where the dummy variable for EXEC_DIR as per Execucomp is "TRUE" across officers of a firm for each firm year.

proportion of the top five officers that is subject to interlock relations calculated as the average of cases where the dummy variable for PINTRLOC flag, as per Execucomp is "TRUE" across officers of a firm for each firm year.

number of board meetings

sum of an industry's (two-digit SIC) squared market shares (in percentages) as in Defond and Park (1999). 


\section{Table III \\ Median Regressions of Change in CEO Compensation on Talent Proxies and Control Variables}

The table presents median regression results for the final sample of 2,343 CEO-firm years with data on both press mentions of CEOs (Articles below) and industry-adjusted average ROA over the last three years (IndadjROA below) and consists of officers named as CEOs of all S\&P 500 companies during the period 1993 to 2001 in the Execucomp database after eliminating CEO firm-years with missing data from Compustat and CRSP. Median regressions minimize the sum of absolute deviations rather than the sum of squared deviations. The dependent variable is the change in total compensation (sum of total flow compensation and change in the market value of the CEO's stock and options). The independent variables include the change in shareholder-wealth firm (beginning of the year market value of the firm multiplied by percent returns for the firm); change in shareholder-wealth index (beginning of the year market value of the firm multiplied by percent returns earned by other firms in the same industry for column (1) or by percent returns earned by the S\&P 500 market for column (2)); change in shareholderwealth index interacted with IndadjROA, the empirical cumulative distribution function (CDF) for Articles and CEO tenure; and change in shareholder-wealth firm interacted with the CDF for CEO age, market value of equity (Size below) and beginning of the year market value times the variance of monthly stock returns, expressed in decimal form over the 60 months preceding the data year (Variance of $S W$ below). Column (1) shows that the estimated pay-for-performance (PPS) for a CEO in our sample with a minimum/median/maximum $F$ (Articles) and IndadjROA is $\$ 8.00 / \$ 8.70 / \$ 9.25$ for a thousand dollar increase in the market value of the firm. The PPS is computed by evaluating the regression coefficients at the median values of the CDF of the control variables.

\begin{tabular}{|c|c|c|c|}
\hline \multicolumn{4}{|c|}{ Dependent Variable: $\Delta$ Total Compensation } \\
\hline Independent Variables & Predicted sign & $\begin{array}{l}\text { Industry } \\
\text { Index (1) }\end{array}$ & $\begin{array}{c}\text { Market } \\
\text { Index (2) }\end{array}$ \\
\hline$\Delta \mathrm{SW}-$ firm & + & $15.82 *$ & $14.30^{*}$ \\
\hline$\Delta \mathrm{SW}-$ index & $\begin{array}{l}\beta_{2}<0 \text {, weak RPE, } \\
\beta_{1}+\beta_{2}=0 \text {, strong RPE }\end{array}$ & $-2.36^{*}$ & $-6.83 *$ \\
\hline$\Delta \mathrm{SW}-$ index $* \mathrm{~F}($ Articles $)$ & $+\mathrm{H} 1$ & $0.77 *$ & $1.56^{*}$ \\
\hline$\Delta \mathrm{SW}-$ index $*$ IndadjROA & $+\mathrm{H} 1$ & $0.55^{*}$ & $3.75^{*}$ \\
\hline \multicolumn{4}{|l|}{ Controls } \\
\hline$\Delta \mathrm{SW}-$ index $* \mathrm{~F}($ Tenure $)$ & $?$ & $3.22 *$ & $4.93 *$ \\
\hline$\Delta \mathrm{SW}-$ firm $* \mathrm{~F}(\mathrm{CEO}$ age $)$ & $?$ & $-2.67 *$ & $-0.81 *$ \\
\hline$\Delta \mathrm{SW}-$ firm $* \mathrm{~F}($ Size $)$ & $?$ & $-27.66^{*}$ & $-28.34 *$ \\
\hline$\Delta \mathrm{SW}-$ firm $* \mathrm{~F}($ Variance of $\mathrm{SW})$ & $?$ & $16.10^{*}$ & $17.80 *$ \\
\hline Sample Size & & 2,343 & 2,343 \\
\hline Psuedo- $\mathrm{R}^{2}$ & & 0.092 & 0.091 \\
\hline Test Strong RPE: $\beta_{1}+\beta_{2}=0$ ( $\mathrm{p}$ value $)$ & & 0.000 & 0.000 \\
\hline Minimum F(Articles) and IndadjROA & & $\$ 8.00$ & $\$ 4.58$ \\
\hline Median F(Articles) and IndadjROA & & $\$ 8.70$ & $\$ 7.66$ \\
\hline Maximum F(Articles) and IndadjROA & & $\$ 9.25$ & $\$ 9.56$ \\
\hline
\end{tabular}

Notes: $* / \uparrow / \#$ represents statistical significance at the $p$-value $<0.1,0.05,0.10$, respectively and one tailed when coefficient sign is predicted, two-tailed otherwise. Coefficients on intercept, industry and time dummies are suppressed. Since the cumulative distribution functions (cdf) of variables are computed on a yearly basis, estimated pay sensitivities are evaluated at median values of approximately 0.50 for the cdfs of the variables tenure, CEO age, size and variance of SW. Market Index (2) is evaluated at the 0.49 quantile. 


\section{Table IV \\ Median Regressions of Change in CEO Compensation on Talent Proxies to control for the link between CEO talent and PPS}

The table presents median regression results for the equation below for the final sample of 2,343 CEO-firm years with data on both press mentions of CEOs (Articles below) and industry-adjusted average ROA over the last three years (IndadjROA below) and consists of officers named as CEOs of all S\&P 500 companies during the period 1993 to 2001 in the Execucomp database after eliminating CEO firm-years with missing data from Compustat and CRSP. Median regressions minimize the sum of absolute deviations rather than the sum of squared deviations. The dependent variable is the change in total compensation (sum of total flow compensation and change in the market value of the CEO's stock and options). The independent variables include the change in shareholder-wealth firm (beginning of the year market value of the firm multiplied by percent returns for the firm); change in shareholder-wealth index (beginning of the year market value of the firm multiplied by percent returns earned by other firms in the same industry for columns (1) and (2) or by percent returns earned by the S\&P 500 market for columns (3) and (4)); change in shareholder-wealth index interacted with IndadjROA and the empirical cumulative distribution function (CDF) for Articles; and change in shareholder-wealth firm interacted with IndadjROA and the CDF for Articles.

Dependent Variable: $\Delta$ Total Compensation

\begin{tabular}{|c|c|c|c|c|c|}
\hline Variable & Predicted sign & $\begin{array}{l}\text { Industry } \\
\text { Index (1) }\end{array}$ & $\begin{array}{l}\text { Industry } \\
\text { Index (2) }\end{array}$ & $\begin{array}{c}\text { Market } \\
\text { Index (3) }\end{array}$ & $\begin{array}{c}\text { Market } \\
\text { Index (4) }\end{array}$ \\
\hline$\Delta \mathrm{SW}$ - firm & + & $2.65^{*}$ & $2.21 *$ & $2.49 *$ & $3.31^{*}$ \\
\hline$\Delta \mathrm{SW}$ - index & $\begin{array}{l}\beta_{2}<0 \text {, weak RPE, } \\
\beta_{1}+\beta_{2}=0 \text {, strong RPE }\end{array}$ & $-0.38 *$ & -0.05 & $-1.87 *$ & $-6.42 *$ \\
\hline$\Delta \mathrm{SW}-$ index $* \mathrm{~F}($ Articles $)$ & $+\mathrm{H} 1$ & $0.46^{*}$ & & $1.01 *$ & \\
\hline$\Delta \mathrm{SW}-$ index $*$ IndadjROA & $+\mathrm{H} 1$ & & $-0.23 \#$ & & $6.43^{*}$ \\
\hline \multicolumn{6}{|l|}{ Milbourn's variables } \\
\hline$\Delta \mathrm{SW}-$ firm $* \mathrm{~F}$ (Articles) & + & $0.50^{*}$ & & $0.80 *$ & \\
\hline$\Delta \mathrm{SW}-$ firm $*$ IndadjROA & + & & $2.02 *$ & & $0.80^{*}$ \\
\hline Sample Size & & 3,487 & 2,343 & 3,487 & 2,343 \\
\hline Psuedo- $\mathrm{R}^{2}$ & & 0.061 & 0.069 & 0.061 & 0.069 \\
\hline Test Strong RPE: $\beta_{1}+\beta_{2}=0$ ( $p$ value $)$ & & 0.000 & 0.000 & 0.000 & 0.000 \\
\hline
\end{tabular}

Notes: $* / \uparrow / \#$ represents statistical significance at the $p$-value $<0.1,0.05,0.10$, respectively and one tailed when coefficient sign is predicted, two-tailed otherwise. Coefficients on intercept, industry and time dummies are suppressed. 


\section{Table V \\ Median Regressions of Change in CEO Compensation on Talent Proxies: Skimming Explanation}

The table presents median regression results for the final sample of 2,343 CEO-firm years with data on both press mentions of CEOs (Articles below) and industry-adjusted average ROA over the last three years (IndadjROA below) and consists of officers named as CEOs of all S\&P 500 companies during the period 1993 to 2001 in the Execucomp database after eliminating CEO firm-years with missing data from Compustat and CRSP. Median regressions minimize the sum of absolute deviations rather than the sum of squared deviations. The dependent variable is the change in total compensation (sum of total flow compensation and change in the market value of the CEO's stock and options). The independent variables include the change in shareholder-wealth firm (beginning of the year market value of the firm multiplied by percent returns for the firm); change in shareholder-wealth index (beginning of the year market value of the firm multiplied by percent returns earned by other firms in the same industry for column (1) or by percent returns earned by the S\&P 500 market for column (2)); change in shareholderwealth-index interacted with IndadjROA and the empirical cumulative distribution function (CDF) for Articles and CEO tenure; change in shareholder wealth-firm interacted with the CDF for CEO age, market value of equity (Size below) and beginning of the year market value times the variance of monthly stock returns, expressed in decimal form over the 60 months preceding the data year (Variance of SW below); and change in shareholder-wealth index interacted with each of the following skimming variables: measure of shareholder rights as compiled by Gompers, Ishii and Metrick (2003), a dummy variable coded one if the CEO is the chairman of the board, the proportion of the executive team serving on the board, the proportion of the executive team subject to interlocked relation, and the number of board meetings held during the year. Column (1) shows that the estimated pay-for-performance (PPS) for a CEO in our sample with a minimum/median/maximum F(Articles) and IndadjROA is $\$ 8.19 / \$ 9.18 / \$ 9.89$ for a thousand dollar increase in the market value of the firm. The PPS is computed by evaluating the regression coefficients at the median values of the CDF of the control and skimming variables.

\begin{tabular}{|c|c|c|c|}
\hline \multicolumn{4}{|c|}{ Dependent Variable: $\Delta$ Total Compensation } \\
\hline Variable & Predicted sign & $\begin{array}{l}\text { Industry } \\
\text { Index (1) }\end{array}$ & $\begin{array}{c}\text { Market } \\
\text { Index (2) }\end{array}$ \\
\hline$\Delta \mathrm{SW}$ - firm & + & $15.90^{*}$ & $14.50^{*}$ \\
\hline$\Delta \mathrm{SW}$ - index & $\begin{array}{l}\beta_{2}<0, \text { weak RPE, } \\
\beta_{1}+\beta_{2}=0 \text {, strong RPE }\end{array}$ & $-0.75^{*}$ & $-3.06^{*}$ \\
\hline$\Delta \mathrm{SW}-$ index $* \mathrm{~F}($ Articles $)$ & $+\mathrm{H} 1$ & $0.85^{*}$ & $1.61^{*}$ \\
\hline$\Delta \mathrm{SW}$ - index $*$ IndadjROA & $+\mathrm{H} 1$ & $0.95 *$ & $5.28 *$ \\
\hline Skimming explanation & If skimming: & & \\
\hline$\Delta \mathrm{SW}-$ index $* \mathrm{~g}$ score & + & $-0.02 *$ & $-0.08 *$ \\
\hline$\Delta \mathrm{SW}-$ index $*$ CEO-Chair & + & $1.10^{*}$ & $3.14 *$ \\
\hline$\Delta \mathrm{SW}-$ index $*$ Onboard & + & $0.36^{*}$ & $-4.70 *$ \\
\hline$\Delta \mathrm{SW}-$ index $*$ Interlock & + & $2.64 *$ & 2.48 \\
\hline$\Delta \mathrm{SW}-$ index $*$ Meetings & - & $-0.32 *$ & $-0.58 *$ \\
\hline \multicolumn{4}{|l|}{ Controls } \\
\hline$\Delta \mathrm{SW}-$ index $* \mathrm{~F}($ Tenure $)$ & $?$ & $2.69 *$ & $5.09 *$ \\
\hline$\Delta \mathrm{SW}-$ firm $* \mathrm{~F}(\mathrm{CEO}$ age $)$ & $?$ & $-3.17 *$ & $-0.83 *$ \\
\hline$\Delta \mathrm{SW}-$ firm $* \mathrm{~F}($ Size $)$ & $?$ & $-27.24 *$ & $-28.12 *$ \\
\hline$\Delta \mathrm{SW}-$ firm $* \mathrm{~F}($ Variance of $\mathrm{SW})$ & $?$ & $16.10^{*}$ & $17.31^{*}$ \\
\hline Sample Size & & 2,343 & 2,343 \\
\hline Psuedo- $\mathrm{R}^{2}$ & & 0.096 & 0.093 \\
\hline Test Strong RPE: $\beta_{1}+\beta_{2}=0$ ( $p$ value $)$ & & 0.000 & 0.000 \\
\hline
\end{tabular}




\section{Table V -- Continued}

\begin{tabular}{|c|c|c|}
\hline \multicolumn{3}{|c|}{ Estimated Pay Sensitivities Assuming Median Control and Skimming explanation variables } \\
\hline Minimum F(Articles) and IndadjROA & \$\$8.19 & $\$ 5.59$ \\
\hline Median F(Articles) and IndadjROA & $\$ 9.18$ & $\$ 9.65$ \\
\hline Maximum F(Articles) and IndadjROA & $\$ 9.89$ & $\$ 12.04$ \\
\hline \multicolumn{3}{|c|}{$\begin{array}{l}\text { Notes: } * / \uparrow / \# \text { represents statistical significance at the } p \text {-value }<0.1,0.05,0.10 \text {, respectively and one tailed when } \\
\text { coefficient sign is predicted, two-tailed otherwise. Coefficients on intercept, industry and time dummies are } \\
\text { suppressed. Since the cumulative distribution functions (cdf) of variables are computed on a yearly basis, estimated } \\
\text { pay sensitivities are evaluated at median values of approximately } 0.50 \text { for the cdfs of the variables tenure, CEO age, } \\
\text { size and variance of SW. The median values used for } D_{\mathrm{g} \text { score }}{ }^{*} \mathrm{~g} \text { score, CEO-Chair, Onboard, Interlock and Meetings } \\
\text { are } 9,1,0.30,0 \text { and } 7.0 \text {, respectively. }\end{array}$} \\
\hline
\end{tabular}




\section{Table VI \\ Median Regressions of Change in CEO Compensation on Talent Proxies: Oligopoly Explanation}

The table presents median regression results for the final sample of 2,343 CEO-firm years with data on both press mentions of CEOs (Articles below) and industry-adjusted average ROA over the last three years (IndadjROA below) and consists of officers named as CEOs of all S\&P 500 companies during the period 1993 to 2001 in the Execucomp database after eliminating CEO firm-years with missing data from Compustat and CRSP. Median regressions minimize the sum of absolute deviations rather than the sum of squared deviations. The dependent variable is the change in total compensation (sum of total flow compensation and change in the market value of the CEO's stock and options). The independent variables include the change in shareholder-wealth firm (beginning of the year market value of the firm multiplied by percent returns for the firm); change in shareholder-wealth index (beginning of the year market value of the firm multiplied by percent returns earned by other firms in the same industry for column (1) or by percent returns earned by the S\&P 500 market for column (2)); change in shareholderwealth index interacted with IndadjROA and the empirical cumulative distribution function (CDF) for Articles and CEO tenure; change in shareholder-wealth firm interacted with the CDF of CEO age, market value of equity (Size below) and beginning of the year market value times the variance of monthly stock returns, expressed in decimal form over the 60 months preceding the data year (Variance of SW below); and change in shareholder-wealth index interacted with Independent variables also include the change in shareholder-wealth index interacted with the following oligopoly variable: sum of the industry's squared market share in percentages as in Defond and Park (1999) (Herfindahl-Hierschman Index below). Column (1) shows that the estimated pay-for-performance (PPS) for a CEO in our sample with a minimum/median/maximum $F$ (Articles) and IndadjROA is $\$ 8.03 / \$ 8.65 / \$ 9.19$ for a thousand dollar increase in the market value of the firm. The PPS is computed by evaluating the regression coefficients at the median values of the CDF of the control and oligopoly variables.

\begin{tabular}{|c|c|c|c|}
\hline \multicolumn{4}{|c|}{ Dependent Variable: $\Delta$ Total Compensation } \\
\hline Variable & Predicted sign & $\begin{array}{l}\text { Industry } \\
\text { Index (1) }\end{array}$ & $\begin{array}{c}\text { Market } \\
\text { Index (2) }\end{array}$ \\
\hline$\Delta \mathrm{SW}-$ firm & + & $15.73^{*}$ & $14.13^{*}$ \\
\hline$\Delta \mathrm{SW}$ - index & $\begin{array}{l}\beta_{2}<0, \text { weak RPE, } \\
\beta_{1}+\beta_{2}=0 \text {, strong RPE }\end{array}$ & $-2.39 *$ & $-6.37 *$ \\
\hline$\Delta \mathrm{SW}-$ index $* \mathrm{~F}($ Articles $)$ & $+\mathrm{H} 1$ & $0.87 * *$ & $1.41^{*}$ \\
\hline$\Delta \mathrm{SW}-$ index $*$ IndadjROA & $+\mathrm{H} 1$ & $0.35 \dagger$ & $3.99 *$ \\
\hline \multicolumn{4}{|l|}{ Oligopoly explanation } \\
\hline$\Delta \mathrm{SW}-$ index $*$ Herfindahl-Hierschman Index & $\begin{array}{l}+ \text { if less RPE in } \\
\text { concentrated industry }\end{array}$ & $-0.28 *$ & $-1.63 *$ \\
\hline \multicolumn{4}{|l|}{ Controls } \\
\hline$\Delta \mathrm{SW}-$ index $* \mathrm{~F}($ Tenure $)$ & $?$ & $3.48^{*}$ & $4.83^{*}$ \\
\hline$\Delta \mathrm{SW}-$ firm $* \mathrm{~F}(\mathrm{CEO}$ age $)$ & $?$ & $-2.60 *$ & $-0.84^{*}$ \\
\hline$\Delta \mathrm{SW}-$ firm $* \mathrm{~F}($ Size $)$ & $?$ & $-27.64 *$ & $-28.21^{*}$ \\
\hline$\Delta \mathrm{SW}-$ firm $* \mathrm{~F}($ Variance of $\mathrm{SW})$ & $?$ & $16.16^{*}$ & $17.92 *$ \\
\hline Sample Size & & 2,343 & 2,343 \\
\hline Psuedo- $\mathrm{R}^{2}$ & & 0.094 & 0.092 \\
\hline Test Strong RPE: $\beta_{1}+\beta_{2}=0$ ( $p$ value) & & 0.000 & 0.000 \\
\hline
\end{tabular}


Table VI -- Continued

\begin{tabular}{lcc}
\hline \hline \multicolumn{2}{c}{ Estimated Pay Sensitivities Assuming Median Control and Oligopoly explanation variables } \\
\hline \hline Minimum F(Articles) and IndadjROA & $\$ 8.03$ & $\$ 4.69$ \\
Median F(Articles) and IndadjROA & $\$ 8.65$ & $\$ 7.86$ \\
Maximum F(Articles) and IndadjROA & $\$ 9.19$ & $\$ 9.76$ \\
& & \\
\hline
\end{tabular}

Notes: $* / \uparrow / \#$ represents statistical significance at the $p$-value $<0.1,0.05,0.10$, one tailed when coefficient sign is predicted, two-tailed otherwise. Coefficients on intercept, industry and time dummies are suppressed. Since the cumulative distribution functions (cdf) of variables are computed on a yearly basis, estimated pay sensitivities are evaluated at median values of approximately 0.50 for the cdfs of the variables tenure, CEO age, size and variance of SW. The median value used for the Herfindahl-Hierschman Index is 0.15 . 


\section{Table VII \\ Median Regressions of Change in CEO Compensation on Talent Proxies: Hedging Explanation}

The table presents median regression results for the final sample of 2,343 CEO-firm years with data on both press mentions of CEOs (Articles below) and industry-adjusted average ROA over the last three years (IndadjROA below) and consists of officers named as CEOs of all S\&P 500 companies during the period 1993 to 2001 in the Execucomp database after eliminating CEO firm-years with missing data from Compustat and CRSP. Median regressions minimize the sum of absolute deviations rather than the sum of squared deviations. The dependent variable is the change in total compensation (sum of total flow compensation and change in the market value of the CEO's stock and options). The independent variables include the change in shareholder-wealth firm (beginning of the year market value of the firm multiplied by percent returns for the firm); change in shareholder-wealth index (beginning of the year market value of the firm multiplied by percent returns earned by other firms in the same industry for column (1) or by percent returns earned by the S\&P 500 market for column (2)); change in shareholderwealth-index interacted with IndadjROA and the empirical cumulative distribution function (CDF) for Articles and CEO tenure; change in shareholder wealth-firm interacted with the CDF for CEO age, market value of equity (Size below) and beginning of the year market value times the variance of monthly stock returns, expressed in decimal form over the 60 months preceding the data year (Variance of SW below); and change in shareholder-wealth index interacted with each of the following skimming variables: CEO age and CEO firm specific wealth at the start of the year. Column (1) shows that the estimated pay-forperformance (PPS) for a CEO in our sample with a minimum/median/maximum F(Articles) and IndadjROA is $\$ 9.17 / \$ 8.31 / \$ 8.01$ for a thousand dollar increase in the market value of the firm. The PPS is computed by evaluating the regression coefficients at the median values of the CDF of the control and hedging variables.

\begin{tabular}{|c|c|c|c|}
\hline \multicolumn{4}{|c|}{ Dependent Variable: $\Delta$ Total Compensation } \\
\hline Variable & Predicted sign & $\begin{array}{l}\text { Industry } \\
\text { Index (1) }\end{array}$ & $\begin{array}{c}\text { Market } \\
\text { Index (2) }\end{array}$ \\
\hline$\Delta \mathrm{SW}-$ firm & + & $18.19^{*}$ & $14.80 *$ \\
\hline$\Delta \mathrm{SW}-$ index & $\begin{array}{l}\beta_{2}<0, \text { weak RPE, } \\
\beta_{1}+\beta_{2}=0 \text {, strong RPE }\end{array}$ & $-4.79 *$ & $-7.98 *$ \\
\hline$\Delta \mathrm{SW}-$ index $* \mathrm{~F}($ Articles $)$ & $+\mathrm{H} 1$ & $0.39 *$ & 0.13 \\
\hline$\Delta \mathrm{SW}-$ index $*$ IndadjROA & $+\mathrm{H} 1$ & $-1.65^{*}$ & 0.37 \\
\hline Hedging explanation & If hedging: & & \\
\hline$\Delta \mathrm{SW}-$ index $* \mathrm{~F}(\mathrm{CEO}$ age $)$ & + & $-0.87 *$ & $-5.80^{*}$ \\
\hline $\begin{array}{l}\triangle \mathrm{SW}-\text { index } * \mathrm{~F}(\mathrm{CEO} \text { firm specific wealth at the } \\
\text { start of the year) }\end{array}$ & + & $7.93 *$ & $11.16^{*}$ \\
\hline Controls & & & \\
\hline$\Delta \mathrm{SW}-$ index $* \mathrm{~F}($ Tenure $)$ & $?$ & $1.96^{*}$ & $5.62 *$ \\
\hline$\Delta \mathrm{SW}-$ firm $* \mathrm{~F}(\mathrm{CEO}$ age $)$ & $?$ & $-2.90 *$ & $-0.39 *$ \\
\hline$\Delta \mathrm{SW}-$ firm $* \mathrm{~F}($ Size $)$ & $?$ & $-26.26 *$ & $-28.28 *$ \\
\hline$\Delta \mathrm{SW}-$ firm $* \mathrm{~F}($ Variance of SW $)$ & $?$ & $11.95^{*}$ & $16.79 *$ \\
\hline Sample Size & & 2,343 & 2,343 \\
\hline Psuedo- $\mathrm{R}^{2}$ & & 0.098 & 0.094 \\
\hline Test Strong RPE: $\beta_{1}+\beta_{2}=0$ ( $p$ value $)$ & & 0.000 & 0.000 \\
\hline
\end{tabular}




\section{Table VII -- Continued}

\begin{tabular}{lcc}
\hline \hline \multicolumn{2}{c}{ Estimated Pay Sensitivities Assuming Median Control and Hedging explanation variables } \\
\hline \hline Minimum F(Articles) and IndadjROA & $\$ 9.17$ & $\$ 6.34$ \\
Median F(Articles) and IndadjROA & $\$ 8.31$ & $\$ 6.63$ \\
Maximum F(Articles) and IndadjROA & $\$ 8.01$ & $\$ 6.81$ \\
& & \\
\hline
\end{tabular}

Notes: $* / \uparrow / \#$ represents statistical significance at the $p$-value $<0.1,0.05,0.10$, respectively and one tailed when coefficient sign is predicted, two-tailed otherwise. Coefficients on intercept, industry and time dummies are suppressed. Since the cumulative distribution functions (cdf) of variables are computed on a yearly basis, estimated pay sensitivities are evaluated at median values of approximately 0.50 for the cdfs of the variables tenure, CEO age, Firm specific wealth at the start of the year, size and variance of SW. 


\section{Table VIII \\ Median Regressions of Change in CEO Compensation on Talent Proxies: Asymmetric Benchmarking Explanation}

The table presents median regression results for the final sample of CEO-firm years with data on both press mentions of CEOs (Articles below) and industry-adjusted average ROA over the last three years (IndadjROA below) and consists of officers named as CEOs of all S\&P 500 companies during the period 1993 to 2001 in the Execucomp database after eliminating CEO firm-years with missing data from Compustat and CRSP. Median regressions minimize the sum of absolute deviations rather than the sum of squared deviations. The dependent variable is the change in total compensation (sum of total flow compensation and change in the market value of the CEO's stock and options). The independent variables include the change in shareholder-wealth firm (beginning of the year market value of the firm multiplied by percent returns for the firm); change in shareholder-wealth index (beginning of the year market value of the firm multiplied by percent returns earned by other firms in the same industry for column (1) or by percent returns earned by the S\&P 500 market for column (2)); change in shareholderwealth index interacted with IndadjROA and the empirical cumulative distribution function (CDF) for Articles and CEO tenure; and change in shareholder-wealth firm interacted with the CDF for CEO age, market value of equity (Size below) and beginning of the year market value times the variance of monthly stock returns, expressed in decimal form over the 60 months preceding the data year (Variance of $S W$ below). Column (1) shows that the estimated pay-for-performance (PPS) for a CEO in our sample with a minimum/median/maximum $F$ (Articles) and IndadjROA is $\$ 7.28 / \$ 8.78 / \$ 9.85$ for a thousand dollar increase in the market value of the firm. The PPS is computed by evaluating the regression coefficients at the median values of the CDF of the control variables. Panel A presents the median regression results for when the industry or market index was up using 1,747 and 1,629 CEO-firm years, respectively, and Panel $\mathrm{B}$ presents the median regression results for when the industry or market index was down using 596 and 714 CEO-firm years, respectively.

Panel A: Asymmetric Benchmarking Explanation when the Index is Up

\begin{tabular}{|c|c|c|c|}
\hline & \multicolumn{3}{|c|}{ Dependent Variable: $\Delta$ Total Compensation } \\
\hline Variable & Predicted sign & $\begin{array}{l}\text { Industry } \\
\text { Index (1) }\end{array}$ & $\begin{array}{c}\text { Market } \\
\text { Index (2) }\end{array}$ \\
\hline$\Delta \mathrm{SW}-$ firm & + & $16.11^{*}$ & $15.43^{*}$ \\
\hline$\Delta \mathrm{SW}-$ index & $\begin{array}{l}\beta_{2}<0, \text { weak RPE, } \\
\beta_{1}+\beta_{2}=0, \text { strong RPE }\end{array}$ & $-3.09 *$ & $-10.70^{*}$ \\
\hline$\Delta \mathrm{SW}-$ index $* \mathrm{~F}($ Articles $)$ & $+\mathrm{H} 1$ & $1.30 *$ & $4.34 *$ \\
\hline$\Delta \mathrm{SW}$ - index $*$ IndadjROA & $+\mathrm{H} 1$ & $1.42 *$ & $6.88^{*}$ \\
\hline \multicolumn{4}{|l|}{ Controls } \\
\hline$\Delta \mathrm{SW}-$ index $* \mathrm{~F}($ Tenure $)$ & $?$ & $3.31 *$ & $10.79 *$ \\
\hline$\Delta \mathrm{SW}-$ firm $* \mathrm{~F}(\mathrm{CEO}$ age $)$ & $?$ & $-3.68 *$ & $-1.91 *$ \\
\hline$\Delta \mathrm{SW}-$ firm $* \mathrm{~F}($ Size $)$ & $?$ & $-26.30 *$ & $-29.44 *$ \\
\hline$\Delta \mathrm{SW}-$ firm $* \mathrm{~F}($ Variance of $\mathrm{SW})$ & $?$ & $14.97 *$ & $17.90^{*}$ \\
\hline Sample Size & & 1,747 & 1,629 \\
\hline Psuedo- $\mathrm{R}^{2}$ & & 0.096 & 0.082 \\
\hline Test Strong RPE: $\beta_{1}+\beta_{2}=0$ ( $\mathrm{p}$ value) & & 0.000 & 0.000 \\
\hline
\end{tabular}


Table VIII -- Continued

\begin{tabular}{lrr}
\hline \hline \multicolumn{2}{c}{ Estimated Pay Sensitivities Assuming Median Control variables } & \\
\hline \hline Minimum F(Articles) and IndadjROA & $\$ 7.28$ & $\$ 4.04$ \\
Median F(Articles) and IndadjROA & $\$ 8.78$ & $\$ 10.37$ \\
Maximum F(Articles) and IndadjROA & $\$ 9.85$ & $\$ 14.60$ \\
& & \\
\hline
\end{tabular}

Notes: $* / \uparrow / \#$ represents statistical significance at the $p$-value $<0.1,0.05,0.10$, respectively and one tailed when coefficient sign is predicted, two-tailed otherwise. Coefficients on intercept, industry and time dummies are suppressed. Since the cumulative distribution functions (cdf) of variables are computed on a yearly basis, estimated pay sensitivities are evaluated at median values of approximately 0.50 for the cdfs of the variables tenure, CEO age, size and variance of SW.

Panel B: Asymmetric Benchmarking Explanation when the Index is Down

\begin{tabular}{|c|c|c|c|}
\hline Variable & Predicted sign & $\begin{array}{l}\text { Industry } \\
\text { Index (1) }\end{array}$ & $\begin{array}{c}\text { Market } \\
\text { Index (2) }\end{array}$ \\
\hline$\Delta \mathrm{SW}$ - firm & + & $13.30^{*}$ & $13.87^{*}$ \\
\hline$\Delta \mathrm{SW}$ - index & $\begin{array}{l}\beta_{2}<0 \text {, weak RPE, } \\
\beta_{1}+\beta_{2}=0 \text {, strong RPE }\end{array}$ & $-2.74 *$ & -0.70 \\
\hline$\Delta \mathrm{SW}-$ index $* \mathrm{~F}($ Articles $)$ & $+\mathrm{H} 1$ & $1.10^{*}$ & $-2.32 *$ \\
\hline$\Delta \mathrm{SW}-$ index $*$ IndadjROA & $+\mathrm{H} 1$ & $0.83 *$ & -1.07 \\
\hline \multicolumn{4}{|l|}{ Controls } \\
\hline$\Delta \mathrm{SW}-$ index $* \mathrm{~F}($ Tenure $)$ & $?$ & $2.93 *$ & $2.36^{*}$ \\
\hline$\Delta \mathrm{SW}-$ firm $* \mathrm{~F}(\mathrm{CEO}$ age $)$ & $?$ & $0.77 *$ & $-0.41 *$ \\
\hline$\Delta \mathrm{SW}-$ firm $* \mathrm{~F}($ Size $)$ & $?$ & $-27.94 *$ & $-30.60 *$ \\
\hline$\Delta \mathrm{SW}-$ firm $* \mathrm{~F}($ Variance of SW $)$ & $?$ & $17.33 *$ & $20.28 *$ \\
\hline Sample Size & & 596 & 714 \\
\hline Psuedo- $\mathrm{R}^{2}$ & & 0.103 & 0.141 \\
\hline Test Strong RPE: $\beta_{1}+\beta_{2}=0$ ( $p$ value) & & 0.000 & 0.000 \\
\hline \multicolumn{4}{|c|}{ Estimated Pay Sensitivities Assuming Median Control variables } \\
\hline Minimum F(Articles) and IndadjROA & & $\$ \$ 7.21$ & $\$ 8.81$ \\
\hline Median F(Articles) and IndadjROA & & $\$ 8.24$ & $\$ 7.07$ \\
\hline Maximum F(Articles) and IndadjROA & & $\$ 9.04$ & $\$ 7.91$ \\
\hline
\end{tabular}

Notes: $* / \uparrow / \#$ represents statistical significance at the $\mathrm{p}<0.1,0.05,0.10$, respectively and one tailed when coefficient sign is predicted, two-tailed otherwise. Coefficients on intercept, industry and time dummies are suppressed. Since the cumulative distribution functions (cdf) of variables are computed on a yearly basis, estimated pay sensitivities are evaluated at median values of approximately 0.50 for the cdfs of the variables tenure, CEO age, size and variance of SW. Industry Index (1) is evaluated at the 0.49 quantile. 


\section{Notes}

${ }^{1}$ An alternative test of the CEO talent retention hypothesis is to examine CEO turnover in up and down markets. However, such a test has low power because observed turnover is after the retention effects of allowing CEO pay to reflect market returns. That is, if the CEO talent retention hypothesis for the lack of RPE is valid, we expect to observe little ex post CEO turnover.

${ }^{2}$ A priori, we were not sure whether compensation committees employ either the industry return or the overall market return as the benchmark while considering RPE decisions. Hence, we report results related to both the industry and the market index.

${ }^{3}$ Computing industry-adjusted ROA over three prior years restricts the final sample to firms where the CEO has at least three prior years of seniority. To address the seniority issue and yet provide enough time for the CEO to stay in the job such that the industry-adjusted ROA can serve as a credible proxy for talent, we computed industry-adjusted ROA over the prior two years of the same CEO's tenure. As expected, the number of usable CEO firm-years increases from 2,343 for the three-year ROA sample to 2,754 for the two-year ROA sample. In untabulated results, we find that the reported inferences hold even when the two-year ROA sample is used.

${ }^{4}$ As our starting point, we use the CEO's name as reported in ExecuComp. To avoid understatements, we also search for shortened names (e.g., Bill for William) and to avoid overstatements (potentially associated with common names, such as Smith), we include the company name in the search.

${ }^{5}$ We thank Francis et al. (2004) for sharing their data with us.

${ }^{6}$ Three of the lists provide explicit guidance as to the criteria examined. Worth's list is based on interviews with Wall Street analysts and fund managers, and identifies the top CEOs in terms of delivering long term shareholder value and high integrity. The Financial Times list is based on survey evidence from CEOs around the world, who were asked to identify the three business leaders they admire and respect most. Fortune evaluates women executives on four measures: revenues and profits she controls, the importance of her business in the global economy, the arc of her career, and her impact on culture and society.

${ }^{7}$ As a sensitivity check, we dropped CEOs who have not been in office for the last three years from the three year ROA sample and found that the reported inferences remain unchanged.

${ }^{8}$ In untabulated analyses, we introduced Top as a third proxy for CEO talent in the forthcoming model (3) along with Articles and IndadjROA. Consistent with expectations, we found that the results were somewhat mixed. The interaction of Shareholder wealth-industry index and Top was not significant but the interaction of Shareholder wealth-market index and Top was unexpectedly, negative and statistically significant. However, the interaction of Shareholder wealth-index with either Articles or IndadjROA continues to remain positive and significant, regardless of whether the market or the industry index is considered.

${ }^{9}$ The talent explanation presumes that strong form RPE does not exist in the data. The talent explanation is of course, moot, if the strong form version of RPE holds.

${ }^{10}$ In practice, we rank all observations for a variable in ascending order and then scale each rank by $\mathrm{N}$ such that each observation assumes a value between 0 and 1 .

${ }^{11}$ For example, an OLS estimation of equation (3) without data winsorization, yields

$109.12 * \Delta$ Shareholder Wealth-Firm ${ }_{\mathrm{jt}}-163.46 * \Delta$ Shareholder Wealth-Industry ${ }_{\mathrm{jt}}-3.35^{*} \Delta$ Shareholder WealthIndustry $_{\mathrm{jt}} * F(\text { Articles) })_{\mathrm{jt}}+101.74 * \Delta$ Shareholder Wealth-Industry $_{\mathrm{jt}} *$ IndadjROA $_{\mathrm{jt}}+$ Controls $_{\mathrm{jt}}$ (other coefficients not reported, all reported coefficients significant at $1 \%$ level except -3.35 which has a -statistic of -0.35 ).

After winsorization, we get 
$-10.63 * \Delta$ Shareholder Wealth-Firm ${ }_{\mathrm{jt}}-266.98 * \Delta$ Shareholder Wealth-Industry $_{\mathrm{jt}}+63.72 * \Delta$ Shareholder Wealth-

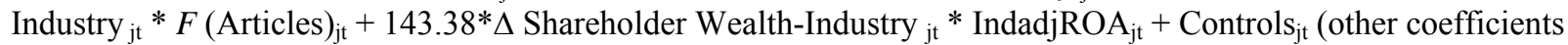
not reported, all reported coefficients at the $1 \%$ level).

Note the big differences in the magnitude of the OLS coefficients relative to the median regression based coefficients reported in Table III.

${ }^{12}$ As a benchmark, note that Aggarwal and Samwick (1999a) report PPS estimates ranging from $\$ 6.59$ to $\$ 14.52$ per \$1000 for the sample period 1993-1996 while Milbourn (2003) reports PPS ranging from \$1.35 for the largest firm to $\$ 25.44$ for the smallest firm. Somewhat smaller PPS estimates in our study are not surprising because our sample consists of S\&P 500 firms and PPS estimates tend to be smaller for larger firms whereas Aggarwal and Samwick (1999a) and Milbourn (2003) focus on a much broader sample of S\&P 1500 firms.

${ }^{13}$ Whether PPS is related positively or negatively to firm risk and whether such an inference is due to the interaction of PPS and size is a subject of much debate in the literature (Aggarwal and Samwick 1999a, Core and Guay 2001, Prendergast 2000). We do not take a position on this issue because the interaction between PPS and (i) size and (ii) variance of shareholder returns (risk) are control variables in our specifications.

${ }^{14}$ Note that we do not present estimated pay sensitivities for minimum and maximum levels of the CEO talent variables here because it would hard to isolate the effect of CEO talent on RPE as such effect is commingled with the effect of CEO talent on PPS in the specification shown in Table IV.

${ }^{15}$ Execucomp codes a dummy variable "EXEC_DIR" as "TRUE" if an executive officer served as director during the indicated fiscal year. In the paper, the ONBOARD variable captures the proportion of officers who are on the board of directors (calculated as the average of cases where the dummy variable is set to TRUE" across officers of a firm for each firm year). Further, an officer is said to have an interlocked relation if that officer a) serves on the compensation committee or b) serves on the board (or compensation committee) of another company that has an executive officer serving on the board (or compensation committee) of his company. Execucomp captures this information for each officer of the firm by setting an indicator variable, PINTRLOC to "TRUE." In the paper, the INTERLOCK variable captures the proportion of officers who have an interlocked relationship (calculated as the average of cases where PINTRLOC is set to "TRUE" across officers of a firm for each firm year).

${ }^{16}$ The oligopolistic industry explanation is a natural fit with the industry index but not with the market index. We present results related to market index here for completeness. 